\title{
Semisynthesis and biological evaluation of amidochelocardin derivatives as broad-spectrum antibiotics
}

Charlotte Grandclaudon ${ }^{\mathrm{a}, \mathrm{b}}$, N. V. Suryanarayana Birudukota ${ }^{\mathrm{a}, \mathrm{b} \S}$, Walid A. M. Elgaher ${ }^{\mathrm{b}, \mathrm{s}}$, Ravindra P. Jumde $^{\mathrm{b}, \mathrm{c}}$, Samir Yahiaoui ${ }^{\mathrm{b}, \mathrm{c}}$, Nanaji Arisetti ${ }^{\mathrm{a}, \mathrm{b}}$, Fabienne Hennessen ${ }^{\mathrm{b}, \mathrm{d}}$, Steffen Bernecker ${ }^{\mathrm{e}}$, Marc Stadler $^{\mathrm{b}, \mathrm{e}}$, Jennifer Herrmann ${ }^{\mathrm{b}, \mathrm{d}}$, Marcus Miethke ${ }^{\mathrm{b}, \mathrm{d}}$, Rolf W. Hartmann ${ }^{\mathrm{b}, \mathrm{c}}$, Rolf Müller ${ }^{\mathrm{b}, \mathrm{d}}$, Anna K. H. Hirsch $^{* b, c}$ and Mark Brönstrup*a,b

[a] Department of Chemical Biology, Helmholtz Centre for Infection Research (HZI), Inhoffenstrasse 7, 38124 Braunschweig, Germany

[b] German Centre for Infection Research (DZIF), Partner site Hannover-Braunschweig, 38124 Braunschweig, Germany

[c] Department of Drug Design and Optimization, Helmholtz Institute for Pharmaceutical Research Saarland (HIPS), Helmholtz Centre for Infection Research (HZI), and Department of Pharmacy, Saarland University, Campus E8.1, 66123 Saarbrücken, Germany

[d] Department of Microbial Natural Products, Helmholtz Institute for Pharmaceutical Research Saarland (HIPS), Helmholtz Centre for Infection Research (HZI), and Department of Pharmacy, Saarland University, Campus E8.1, 66123 Saarbrücken, Germany

[e] Department of Microbial Drugs, Helmholtz Centre for Infection Research (HZI), Inhoffenstrasse 7, 38124 Braunschweig, Germany

$\S \quad$ These authors contributed equally

* Corresponding author: mark.broenstrup@helmholtz-hzi.de, anna.hirsch@helmholtz-hips.de

\begin{abstract}
To address the global challenge of emerging antimicrobial resistance, the hitherto most successful strategy to new antibiotics has been the optimization of validated natural products; most of these efforts rely on semisynthesis. Herein, we report the semisynthetic modification of amidochelocardin, an atypical tetracycline obtained via genetic engineering of the chelocardin producer strain. We report modifications at $\mathrm{C} 4, \mathrm{C} 7, \mathrm{C} 10$ and $\mathrm{C} 11$ by the application of methylation, acylation, electrophilic substitution, and oxidative $\mathrm{C}-\mathrm{C}$ coupling reactions. The antibacterial activity of the reaction products was tested against a panel of Gram-positive and Gram-negative pathogens. The emerging structure-activity relationships (SARs) revealed that positions $\mathrm{C} 7$ and $\mathrm{C} 10$ are favorable anchor points for the semisynthesis of optimized derivatives. The observed SAR was different from that known for tetracyclines, which underlines the pronounced differences between the two compound classes.
\end{abstract}

Keywords: antibiotics, chelocardin, tetracycline, semisynthesis, natural product, Gram-negative bacteria 1 


\section{Introduction}

Efficient antibiotics constitute an indispensable pillar of modern medicine. Therefore, the loss of their efficacy by the emergence of multidrug-resistant bacterial pathogens represents one of the big challenges for global health today.[1-3] Since the current drug-development pipeline is insufficient to counteract antimicrobial resistance, [4] there is an urgent need to find new classes of antibiotics that are able to overcome current resistance mechanisms, ideally by addressing a different mode of action.
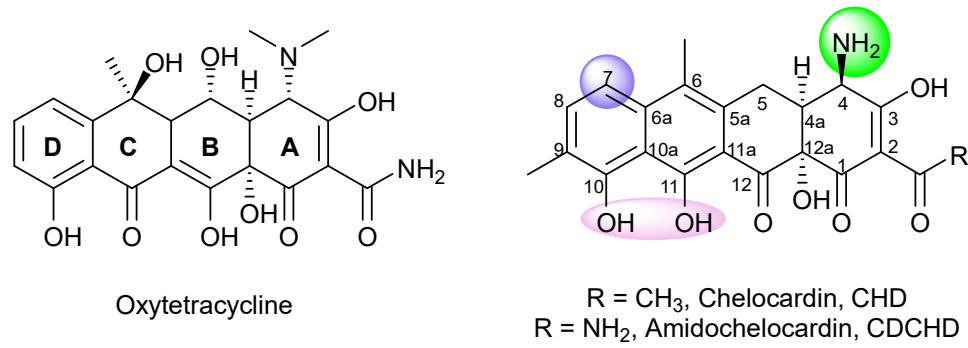

Figure 1. Structures of oxytetracycline, chelocardin and amidochelocardin. Different positions selected for chemical derivatization are marked as colored circles.

Natural products of microbial origin have been the richest source of novel antibiotics so far.[5] One of the strategies to discover novel promising natural product-based lead structures is to re-examine molecules, which were reported as potent antibiotics in the past, but not developed further for various reasons ('look back approach'). In this context chelocardin (CHD), a so-called atypical tetracycline produced by actinomycete Amycolatopsis sulphurea, attracted our interest: The mode of action of CHD, albeit not entirely elucidated, is most likely different from that of the structurally related tetracyclines (Figure 1), as suggested by the lack of cross-resistance and distinct cellular effects. [6-9] Moreover, CHD has demonstrated efficacy in humans in a past phase 2 study and is active against clinically relevant Gram-positive and Gram-negative pathogens. [10] In spite of the similarity of the CHD and tetracycline[11] scaffolds, important structural differences that induce different 3D pharmacophores include (i) the aromatization of ring $\mathrm{C}$, (ii) the presence of a methyl group at $\mathrm{C} 9$ and (iii) the primary amine at $\mathrm{C} 4$. An important progress in chelocardin chemistry was achieved by genetic engineering of the producer strain that led to the replacement of the acetyl group at the $\mathrm{C} 2$ position of CHD by a carboxamido moiety, as prevalent in tetracyclines. The resulting compound, called amidochelocardin or 2-carboxamido-2deacetyl-chelocardin (CDCHD), has on average a 2-4 fold increased antibacterial activity compared to CHD. Remarkably, whereas CHD does not show any activity against Pseudomonas aeruginosa $\left(>64 \mu \mathrm{g} \mathrm{mL}^{-1}\right)$, CDCHD has a $\mathrm{MIC}_{50}$ of $8 \mu \mathrm{g} \mathrm{mL}^{-1}$.[12] These data have encouraged us to select the CDCHD scaffold as a lead structure for a new broad-spectrum antibiotic, and access new derivatives by a combination of biosynthetic engineering[13] and chemical derivatization of CDCHD. This article will focus on our chemical derivatization efforts. Initial plans for late-stage functionalizations of CDCHD were inspired by the synthetic procedures available for tetracyclines, which were among the first natural compounds to be used as semisynthesis platforms. [14] Since Conover's catalytic hydrogenolysis of auromycin (chlorotetracycline) to tetracycline itself at Pfizer in 
1952,[15] many blockbuster antibiotics derived from tetracyclines were obtained by semisynthesis, the most recent being sarecycline[16] and omadacycline[17], both approved by the FDA in 2018. In this study, we report our efforts to functionalize $\mathrm{CDCHD}$ at the most tractable positions for derivatization, namely the $\mathrm{C} 4$ amino group, at the electron-rich $\mathrm{C} 7$ position, and at the $\mathrm{C} 10 / \mathrm{C} 11$ positions.

\section{Derivatization of the $\mathrm{C} 4$ amino function}

Methylation: The primary amine at $\mathrm{C} 4$ is the most nucleophilic position in CDCHD. Given the fact that tetracyclines are $\mathrm{N}, \mathrm{N}$-dimethylated at this position, we hypothesized that a similar substitution would improve the activity of CDCHD. For that purpose, CDCHD was subjected to reductive amination in the presence of paraformaldehyde, triethylamine, and hydrogen gas with palladium on carbon to yield the mono and the disubstituted compounds 1 and 2 (Figure 2A).[18] Harsher agents like methyl iodide led to unselective methylations at a variety of oxygen or nitrogen atoms, even after the protection of the C4-amino group as described below.

Acylation, carbamoylation and sulfonylation: Various functional groups, such as benzyl carbamate, acetyl or methanesulfonamide were introduced under Schotten-Baumann conditions with short reaction times to obtain the respective derivatives 3, 7 and $\mathbf{1 2}$ in yields between 16 and 38\%.[19] The ethyl carbamate $\mathbf{4}$ and the arylamide 11 were prepared by reacting CDCHD with ethyl chloroformate or 4-methoxybenzoyl chloride in THF in the presence of DIPEA in 24 and 31\% yields, respectively. The imides 5 and $\mathbf{6}$ were synthesized by heating CDCHD with maleic anhydride at $100{ }^{\circ} \mathrm{C}$ or phthalic anhydride at $120{ }^{\circ} \mathrm{C}$ in 15 and $18 \%$ yields, respectively. Coupling of CDCHD with $N$-Boc- $\beta$-Ala using propylphosphonic anhydride (T3P) in a mixture of EtOAc and pyridine at 40 ${ }^{\circ} \mathrm{C}$ followed by Boc-deprotection using TFA afforded $\beta$-alanine amide 8 in $5 \%$ yield over two steps. The 4 methylpiperazine-1-acetamide 9 and acrylamide 10 were obtained from the reaction between CDCHD and the corresponding acid chloride in $N$-methyl-2-pyrrolidone (NMP) in 7 and 5\% yields, respectively (Figure 2A).

\section{Derivatization at the $\mathrm{C} 7$ position}

The $\mathrm{C} 7$ position has been a hotspot in tetracycline derivatization, as the chloro-substituent in the first congener has been substituted with hydrogen, dimethylamine, fluorine, or aminoxyalkyl residues. Thus, an aromatic substitution was attempted at the electron-rich position with various electrophiles, beginning with sources of halogens (Figure 2B).

Aromatic electrophilic substitution: To introduce fluorine at the $\mathrm{C} 7$ position, the $\mathrm{C} 4$ amino group was protected with Fmoc in presence of sodium bicarbonate in a mixture of acetonitrile and water with a yield of $27 \%$. An electrophilic fluorination was performed with xenon difluoride in $6 \%$ yield. [20, 21] Deprotection of the amine function in presence of piperidine in $N, N$-dimethylformamide afforded compound $\mathbf{1 3}$ in $26 \%$ yield. An alternative protocol used Selectfluor ${ }^{\circledR}$ in acetonitrile to directly fluorinate the unprotected compound to give $\mathbf{1 3}$ in $15 \%$ yield. 


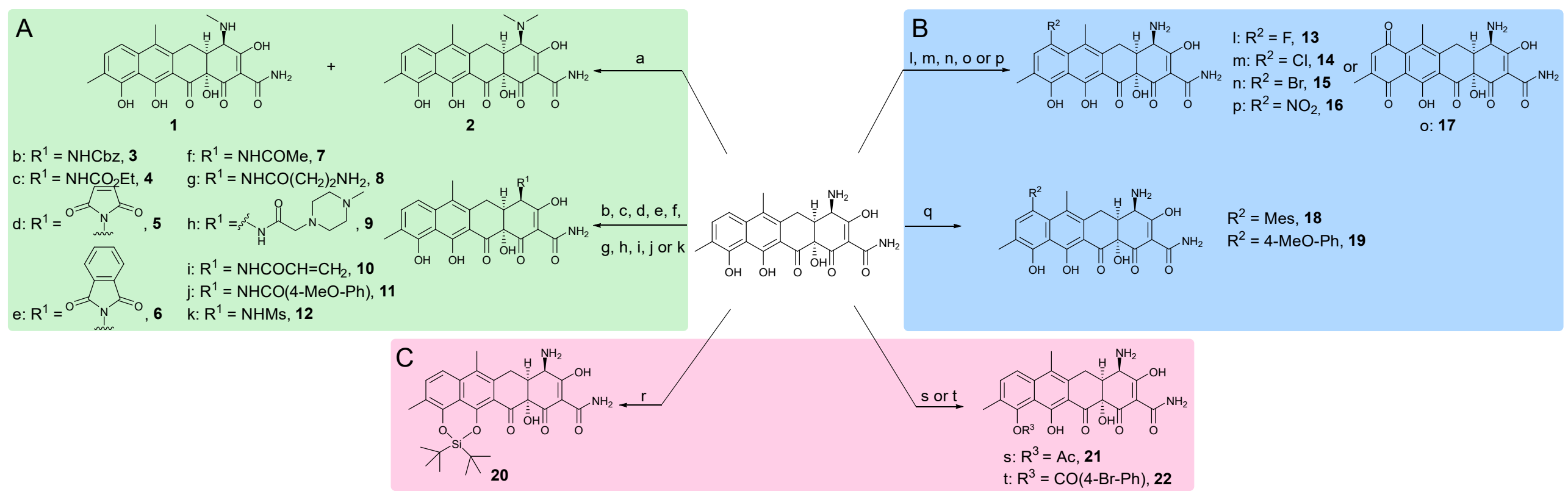

Figure 2: Chemical derivatizations of CDCHD. a) (HCHO) $, \mathrm{NEt}_{3},[\mathrm{Pd} / \mathrm{C}], \mathrm{H}_{2} 1 \mathrm{~atm}, \mathrm{MeOH}, \mathrm{rt}, 18 \mathrm{~h}, 4 \%$ (1) and 11\% (2); b) $\mathrm{CbzCl}, \mathrm{NaHCO}, \mathrm{THF} / \mathrm{H}_{2} \mathrm{O}$, rt, $30 \mathrm{~min}, 30 \%$; c) Ethyl chloroformate, DIPEA, THF, rt, overnight, 24\%; d) Maleic anhydride, acetic acid, $100{ }^{\circ} \mathrm{C}, 48 \mathrm{~h}, 15 \%$; e) Phthalic anhydride, DIPEA, $120^{\circ} \mathrm{C}, 1 \mathrm{~h}, 18 \%$; f) AcCl, $\mathrm{Na}_{2} \mathrm{CO}_{3}$, THF/H $\mathrm{H}_{2} \mathrm{O}$, rt, $30 \mathrm{~min}, 38 \%$; g) 1) $N$-Boc- $\beta$-Ala, T3P, EtOAc, pyridine, $40{ }^{\circ} \mathrm{C}, 17 \mathrm{~h}, 22 \%$ 2) TFA, DCM, rt, $1 \mathrm{~h}, 21 \%$; h) $4-$ Methylpiperazine-1-acetyl chloride, NMP, rt, 16 h, 7\%; i) Acryloyl chloride, NMP, $0{ }^{\circ} \mathrm{C}-\mathrm{rt}, 18 \mathrm{~h}, 5 \%$; j) 4-Methoxybenzoyl chloride, DIPEA, THF, rt, overnight, 31\%; k) MsCl, $\mathrm{NaHCO}_{3}$, THF/ $\mathrm{H}_{2} \mathrm{O}$, rt, $30 \mathrm{~min}, 16 \%$; 1) 1) Fmoc-Cl, $\mathrm{NaHCO}_{3}, \mathrm{MeCN} /$ Water 4:1, rt, $30 \mathrm{~min}, 27 \%$ 2) XeF 2 , DCE, rt, 10 min, $6 \% 3$ ) 20\% piperidine in DMF, rt, 1 h, 26\%; m) NCS, TFA, rt 30 min, 28\%; n) NBS, TFA, rt, 30 min, 17\%; o) NIS, TFA, rt, 30 min, 17\%; p) Nitric acid, sulfolane, 0 ${ }^{\circ} \mathrm{C}, 15 \mathrm{~min}, 4 \%$; q) $\mathrm{PhI}(\mathrm{OAc})_{2}$, AcOH, ArH, HFIP, 3h, rt, 15\% (11), 13\% (12); r) 1) Boc $2 \mathrm{O}, \mathrm{NEt}_{3}, \mathrm{THF}, 1 \mathrm{~h}, 40 \%$, 2) $\left.\mathrm{Si}(\mathrm{tBu})_{2}(\mathrm{OTf})_{2}, \mathrm{NEt} 3, \mathrm{DMF}, 12 \%, 3\right) \mathrm{TFA}$, DCM, rt, 1h, 39\%; s) AcCl 10 equiv., HFIP, rt, 9\%; t) 4-Br-phenylacyl chloride 10 equiv., HFIP, rt, $11 \%$. 
Using trifluoroacetic acid as solvent and stoichiometric amounts of the corresponding $N$-halosuccinimide, the desired chloro- and bromo- derivatives 14 and 15 were isolated in moderate yields.[22] However, the application of $\mathrm{N}$-iodosuccinimide under otherwise identical reaction conditions did not yield an iodinated amidochelocardin, but the quinone $\mathbf{1 7}$ as the major product. We hypothesized that an iodinated compound may be formed initially, that was, however, prone to further oxidation by $\mathrm{N}$-iodosuccinimide and subsequent hydrolysis to result in the quinone scaffold.

Finally, CDCHD was also subjected to nitration using fuming nitric acid in sulfolane at $0{ }^{\circ} \mathrm{C}$. [23] The desired molecule 16 was obtained in a poor yield of $4 \%$. In spite of several attempts to reduce 16, we could not isolate the respective 7 -amino analog.

C-C cross-coupling attempts: The halogenated compounds 14 and 15 opened promising perspectives for further functionalization by metal-catalyzed cross-coupling reactions (Figure 3). Different conditions were tried for Suzuki-Myaura reactions with phenylboronic acid, using palladium[24] or nickel[25, 26] catalysts, but coupling products were not observed by LC-MS, neither with the free C4-amino amidochelocardin nor with the Bocprotected version. Instead, the debrominated compound was formed, indicating that an oxidative insertion was possible, but subsequent steps were unsuccessful. Other types of coupling reactions were attempted, such as Buchwald-Hartwig reactions with various nucleophiles (secondary amines, anilines,[27] thiols[28] and cyanide[29]), but turned out to be non-productive. Stille reactions[30, 31] were performed with the corresponding vinyl and phenyl tin reagents but led predominantly to a dehalogenated product. Ultimately, Ullmann-type reactions were tried in the presence of sodium azide,[32] in order to take advantage of the high nucleophilicity of this species. But even with a stoichiometric amount of copper iodide, no conversion to the desired compound was achieved. Confronted with these difficulties and the additional challenge to work with a small amount of starting material, we examined alternative strategies to form carbon-carbon bonds on the naphthalene-diol moiety.

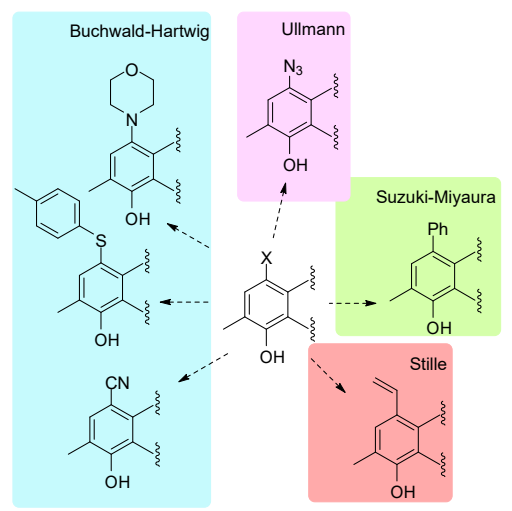


Metal-free $\mathrm{C}-\mathrm{H}$ functionalization: Direct $\mathrm{CH}$-functionalizations appeared as relevant transformations for our substrate,[33] especially as some do not require a protection of the C4-amino group. A metal-free method using hypervalent iodine species for coupling phenols to nucleophilic arenes was reported in 2013 by Morimoto et al. $[34,35]$ According to the proposed mechanism, the iodine (III) reagent allows the formation of a cationic phenoxenium intermediate, which can then react with various electron-rich arenes (Figure 4).

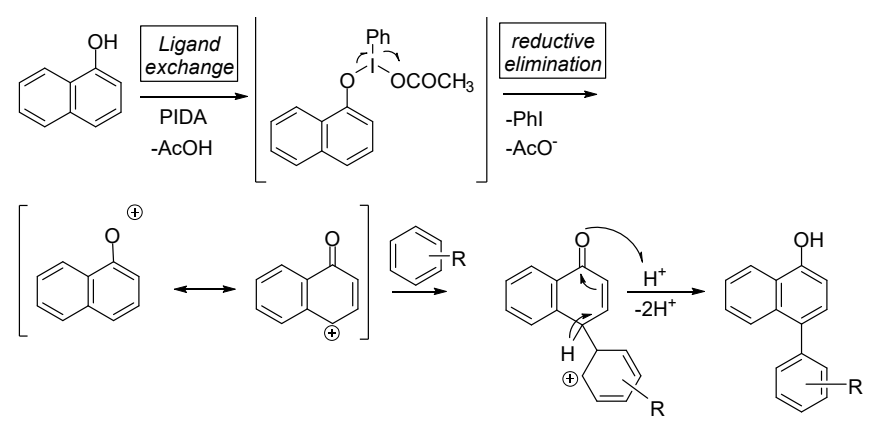

Figure 4: Proposed mechanism for metal free $\mathrm{CH}$-arylation

Indeed, with the substrates mesitylene and anisole, the desired coupling products $\mathbf{1 8}$ and $\mathbf{1 9}$ were obtained in low yields of $15 \%$ and 13\%, respectively (Figure 2B). However, with less nucleophilic substrates like furan, propargylic alcohol or malonates, the corresponding coupling products were not obtained.

\section{Derivatization at the C10 and C11 hydroxy functions}

The modification at the $\mathrm{C} 10$ and $\mathrm{C} 11$ position followed two objectives. First, functional group protection was sought that facilitates derivatization reactions at other positions. Second, the importance of the free $\mathrm{OH}$ groups for antibacterial activity was probed. We note that for tetracyclins, the respective positions are mandatory for activity.

Bis-protection: Trost et al. described the use of the di-tert-butylsilylene protecting group in the preparation of a tetracycline-derived scaffold called deoxypillaromycinone.[36] They investigated particularly the reactivity of various oxygen functions towards silylation and remarkably, naphthalene-1,8-diols were found to be more reactive than aliphatic 1,3- or 1,2-diols. To avoid any issue of selectivity, the C4-amino function of CDCHD was Boc-protected first. Next, the aromatic diol was silylated with $\mathrm{Si}(\mathrm{tBu})_{2}(\mathrm{OTf})_{2}$ in the presence of trimethylamine in DMF (Figure 2C). Cleavage of the Boc protecting group in presence of TFA in methylene chloride gave, after purification by preparative HPLC, the silylene derivative 20 in 39\% yield.

Selective esterification at the C10 position: CDCHD was subjected to Friedel-Crafts acylation in the presence of aluminum chloride and acylchloride under heating conditions. Whereas CDCHD was not converted into the C7acylated product, the use of an excess of acetyl chloride in 1,1,1,3,3,3-hexafluoro-2-propanol (HFIP) at room 
temperature afforded the corresponding O10-acylated ester 21 in a selective manner (Figure 2C).[37] The same conditions were applied with 4-bromobenzoyl chloride to give the ester 22 in $11 \%$ yield. The regioselectivity of these reactions was proven by a shift of the $\mathrm{C} 10$ signal in ${ }^{13} \mathrm{C}-\mathrm{NMR}(\delta=157 \mathrm{ppm}$ in CDCHD and $\delta=148 \mathrm{ppm}$ in 22 using methanol- $\mathrm{d}_{4}$ as solvent) and by a ${ }^{1} \mathrm{H}$ NOESY experiment that exhibited a correlation between protons of the methyl group at C9 and the ortho-proton of the benzoyl ester (see supporting information).

\section{Antimicrobial activity of semisynthetic analogues}

The antibiotic activity of each compound against a panel of clinically relevant Gram-positive and Gramnegative bacteria is summarized in Table 1 (MIC values in $\mu \mathrm{M}$ are given in Table $\mathrm{S} 1$ of the Supporting information). The minimal inhibitory concentration (MIC) data for the $N$-substituted derivatives 1-12 showed that most modifications at the $\mathrm{C} 4$-amino group were not tolerated and dramatically decreased the activity against Gram-negative pathogens ( $>64 \mu \mathrm{g} / \mathrm{mL}$ against Klebsiella pneumoniae and P. aeruginosa). Only small aliphatic substituents with 3-4 atoms (4, 8 and 10) displayed moderate-weak activities against $K$. pneumoniae and Escherichia coli (MIC 16-32 $\mu \mathrm{g} / \mathrm{mL}$ ). On the other hand, the activity against Gram-positive strains (Enterococcus faecium and Staphylococcus aureus) was improved, or at least retained, compared to the parent compounds CHD and CDHCD by introducing bulky hydrophobic substituents such as the carbamates (3 and 4), imides (5 and 6) and the amides (10 and 11) showing very favorable MIC values of $0.125-8 \mu \mathrm{g} / \mathrm{mL}$. On the contrary, small or polar substituents severely diminished the activity against Gram-positive species $(\mathbf{1}, \mathbf{2}$, 7-9 and 12). The reduction of susceptibility in Gram-negative compared to Gram-positive bacteria could be due to poor permeation of the compounds through the Gram-negative cell wall as indicated by regaining the activity of 5, $\mathbf{6}$ and $\mathbf{1 0}$ against $E$. coli in the presence of the permeability enhancer PMBN. Moreover, higher activities of CHD and CDCHD against the efflux mutant $P$. aeruginosa PA14 $\triangle$ mexAB compared to the wild type strain $P$. aeruginosa PA14 imply that efflux plays a role for this chemical class. Remarkably, compound 2, which possesses the same $N, N$-dimethyl feature as the typical tetracyclines, was found to be inactive, thus underlining the potential difference in mode of action between CDCHD and the tetracyclines. These data are consistent with a previous report on four acylated derivatives of CDHCD.[13]Within the C7-substituted, halogenated compound series 13-15, potency seemed to decrease with the atom size $(\mathrm{F}>\mathrm{Cl}>\mathrm{Br})$. In particular, the fluorinated compound showed comparable activities to the parent CDCHD and even had slightly higher potency against $S$. aureus or $P$. aeruginosa. However, an electron-withdrawing group at $\mathrm{C} 7$ is not generally favorable, because the introduction of a nitro group as in $\mathbf{1 6}$ led to a complete loss of activity (MIC > 64 $\mu \mathrm{g} / \mathrm{mL}$ against all strains). The increase of the size of the substituent at $\mathrm{C} 7$, as in $\mathbf{1 8}$ and $\mathbf{1 9}$, also led to a drop in MIC values against Gram-negative bacteria. Nevertheless, $\mathbf{1 8}$ recovered potency against E. coli in the presence of the membrane permeabilizer (PMBN), highlighting a potential size limitation in the compound uptake.

Tetracyclines are known to complex $\mathrm{Mg}^{2+}$ cations with the hydroxy functions of the Southern half of the molecule in order to cross the outer membrane of Gram-negative pathogens via the porin channels OmpF and 
OmpC.[38] The analogs 20-22 were tested to find out whether equivalent essential pharmacophore points exist in amidochelocardins. The quinone 17 showed poor or no activity against $S$. aureus, $K$. pneumoniae and $P$. aeruginosa. The relevance of the phenols for antibacterial activity was further underlined by the silylated $\mathbf{2 0}$, where both phenolic functions are blocked. Indeed, only activity against the Gram-positive $S$. aureus could be detected $(1 \mu \mathrm{g} / \mathrm{mL})$, whereas the activity against Gram-negative pathogens was abolished. A MIC value of $8 \mu \mathrm{g} /$ $\mathrm{mL}$ was measured against $E$. coli in the presence of PMBN, implying that the molecule could traverse a permeabilized outer membrane without metal chelation. Finally, the C10-acylated 21 showed moderate MIC values of $16 \mu \mathrm{g} / \mathrm{mL}$ against Gram-positive strains, no activity against $P$. aeruginosa, and promising activity of 8 $\mu \mathrm{g} / \mathrm{mL}$ against E. coli. Activities against both Gram-negative strains tested were improved in the presence of PMBN, pointing out again an uptake issue by Gram-negative pathogens. Thus in principle, a modified C10 position is compatible with anti-Gram-negative activity. However, the enlargement of the acyl-substituent as in 22 is detrimental for activity against $P$. aeruginosa and $E$. coli, while MIC values of $4 \mu \mathrm{g} / \mathrm{mL}$ were measured against E. faecium and $S$. aureus. In order to exclude that the antibiotic activity of $\mathbf{2 1}$ and $\mathbf{2 2}$ is caused by CDCHD released upon cleavage of the ester function under the experimental conditions, we performed stability measurements in bacterial media. Thus, $\mathbf{2 1}$ and $\mathbf{2 2}$ incubated with medium and medium with $E$. coli were reextracted and analyzed by LC-MS. Both chromatograms revealed the presence of intact $\mathbf{2 1}$ or 22, respectively, and none of them contained a peak of the parent compound CDCHD, confirming the stability of the ester function under the assay conditions (Figure 5).

\section{Conclusions}

This study reports structure-activity relationships of the 'atypical tetracycline' amidochelocardin based on its semisynthetic modification. Notable differences between the CDCHD and the tetracycline SAR supports the biologically-driven hypothesis of their different modes of action. Indeed, we could establish that the replacement of the free amine at $\mathrm{C} 4$ by a dimethylamino group was detrimental for the activity of amidochelocardin against Gram-negative bacteria. We also highlight that small substitutions at the $\mathrm{C} 7$ position as well as ester functions at the $\mathrm{O} 10$ position were tolerated and retained in both Gram-positive and -negative pathogens. A fluorine substitution at $\mathrm{C} 7$ was particularly favorable for antibacterial activity. These positions are currently investigated as anchors for attaching a tag to perform target fishing experiments, which should allow elucidation of the mode of action of these atypical tetracyclines. In general, most reactions had moderate-low yields. This underlines the difficulties of modifying and purifying unprotected, highly functionalized natural products by semisynthesis on small reaction scales of typically $20 \mathrm{mg}$ (or even less) CDCHD. It also implies that the establishment of a total synthesis route to (amido)chelocardin is a worthwhile endeavor to optimize this promising lead structure.

Acknowledgements: This study was supported by the German Ministry of Education and Research (BMBF), grant number 16GW0094K, by the German Centre for Infection Research (DZIF), grant no. TTU09.814/09.821 and by the Helmholtz Association's Initiative and Networking Fund. R.P.J. acknowledges an intra-European 
Marie Sklodowska action fellowship under Horizon 2020 (796089 NovInDXS). We thank Kerstin Schober and Acies Bio (Ljubljana, Slovenia) for support with the production of CDCHD. 
Table 1 : MIC (Minimum Inhibitory Concentration) values of semisynthetic CDCHD derivatives against bacterial pathogens in $\mu \mathrm{g} / \mathrm{mL}$

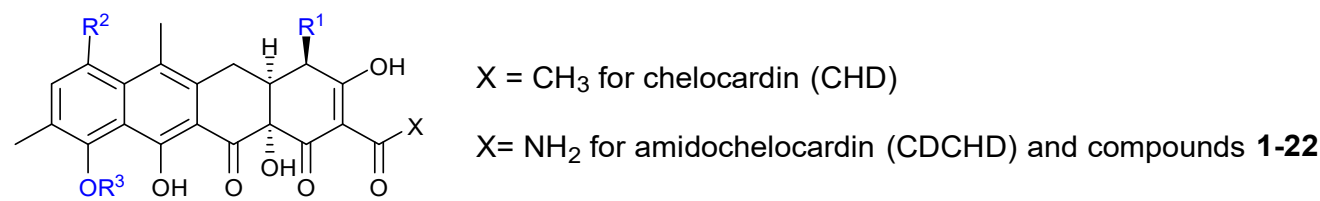

\begin{tabular}{|c|c|c|c|c|c|c|c|c|}
\hline Cmpd & $\mathbf{R}^{1}$ & $\mathbf{R}^{2}$ & $\mathbf{R}^{3}$ & $\begin{array}{l}\text { E. faecium } \\
\text { DSM-20477 }\end{array}$ & S. aureus & $\begin{array}{c}\text { K. pneumoniae } \\
\text { DSM-30104 }\end{array}$ & P. aeruginosa & E. coli \\
\hline $\begin{array}{c}\text { CHD } \\
\text { (Na-citrate) }\end{array}$ & $\mathrm{NH}_{2}$ & $\mathrm{H}$ & $\mathrm{H}$ & 8 & $8^{c}$ & 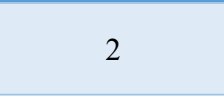 & $64^{\mathrm{d}} ; 4^{\mathrm{f}}$ & $2^{\mathrm{g}}$ \\
\hline $\begin{array}{c}\text { CDCHD } \\
\text { (Na-citrate) }\end{array}$ & $\mathrm{NH}_{2}$ & $\mathrm{H}$ & $\mathrm{H}$ & 4 & $8^{c}$ & 2 & $16^{\mathrm{d}} ; 0.5^{\mathrm{f}}$ & $0.5^{\mathrm{g}}$ \\
\hline 1 & $\mathrm{NHCH}_{3}$ & $\mathrm{H}$ & $\mathrm{H}$ & $>64$ & $>64^{\mathrm{a}}$ & $>64$ & $>64^{\mathrm{d}}$ & - \\
\hline 2 & $\mathrm{~N}\left(\mathrm{CH}_{3}\right)_{2}$ & $\mathrm{H}$ & $\mathrm{H}$ & $>64$ & $>64^{\mathrm{a}}$ & $>64$ & $>64^{\mathrm{d}}$ & - \\
\hline 3 & $\mathrm{NHCBz}$ & $\mathrm{H}$ & $\mathrm{H}$ & 0.25 & $>64^{c}$ & $>64$ & $>64^{\mathrm{d}}$ & - \\
\hline 4 & $\mathrm{NHCO}_{2} \mathrm{Et}$ & $\mathrm{H}$ & $\mathrm{H}$ & - & $2^{\mathrm{c}}$ & 16 & $>64^{\mathrm{d}} ; 64^{\mathrm{f}}$ & - \\
\hline 5 & Maleimide & $\mathrm{H}$ & $\mathrm{H}$ & - & $2^{c}$ & 64 & $>64^{\mathrm{d}, \mathrm{f}}$ & $>64(8)^{\mathrm{h}}$ \\
\hline 6 & Phthalimide & $\mathrm{H}$ & $\mathrm{H}$ & - & $0.125^{\mathrm{c}}$ & $>64$ & $>64^{\mathrm{d}, \mathrm{f}}$ & $>64(0.5)^{\mathrm{h}}$ \\
\hline 7 & NHAc & $\mathrm{H}$ & $\mathrm{H}$ & 32 & $>64^{c}$ & $>64$ & $>64^{d}$ & - \\
\hline 8 & $\begin{array}{c}\mathrm{NHCO}\left(\mathrm{CH}_{2}\right)_{2} \\
\mathrm{NH}_{2}\end{array}$ & $\mathrm{H}$ & $\mathrm{H}$ & $>64$ & $64^{b}$ & - & $32^{\mathrm{f}}$ & $16(8)^{g}$ \\
\hline 9 & $\begin{array}{l}\mathrm{NHCOCH}_{2} \mathrm{~N} \\
\left(\mathrm{C}_{2} \mathrm{H}_{4}\right)_{2} \mathrm{NCH}_{3}\end{array}$ & $\mathrm{H}$ & $\mathrm{H}$ & $>64$ & $>64^{\mathrm{b}}$ & - & $32^{\mathrm{f}}$ & $64(32)^{g}$ \\
\hline 10 & $\mathrm{NHCOCH}=\mathrm{CH}_{2}$ & $\mathrm{H}$ & $\mathrm{H}$ & 8 & $4^{b}$ & - & $>64^{\mathrm{f}}$ & $32(2)^{g}$ \\
\hline 11 & $\begin{array}{l}\text { NHCO-(4- } \\
\left.\mathrm{MeOC}_{6} \mathrm{H}_{4}\right)\end{array}$ & $\mathrm{H}$ & $\mathrm{H}$ & - & $4^{c}$ & $>64$ & $>64^{\mathrm{d}} ; 64^{\mathrm{f}}$ & - \\
\hline 12 & $\mathrm{NHSO}_{2} \mathrm{CH}_{3}$ & $\mathrm{H}$ & $\mathrm{H}$ & 32 & $>64^{c}$ & $>64$ & $>64^{\mathrm{d}}$ & - \\
\hline 13 & $\mathrm{NH}_{2}$ & $\mathrm{~F}$ & $\mathrm{H}$ & - & $4^{c}$ & 8 & $8^{\mathrm{d}} ; 4^{\mathrm{f}}$ & - \\
\hline 14 & $\mathrm{NH}_{2}$ & $\mathrm{Cl}$ & $\mathrm{H}$ & - & $4^{\mathrm{b}}$ & $8(8)$ & $16^{\mathrm{e}}$ & - \\
\hline 15 & $\mathrm{NH}_{2}$ & $\mathrm{Br}$ & $\mathrm{H}$ & - & $8^{\mathrm{b}}$ & $8(4-8)$ & $32^{\mathrm{e}}$ & - \\
\hline 16 & $\mathrm{NH}_{2}$ & $\mathrm{NO}_{2}$ & $\mathrm{H}$ & $>64$ & $>64^{\mathrm{c}}$ & $>64$ & $>64^{\mathrm{d}}$ & - \\
\hline 17 & $\mathrm{NH}_{2}$ & Quinone & - & - & $32^{\mathrm{b}}$ & $>64(64)$ & $>64^{\mathrm{e}}$ & - \\
\hline 18 & $\mathrm{NH}_{2}$ & Mesityl & $\mathrm{H}$ & - & $0.5^{\mathrm{c}}$ & $32-64$ & $>64^{\mathrm{d}}$ & $>64(8)^{\mathrm{h}}$ \\
\hline
\end{tabular}




\begin{tabular}{|c|c|c|c|c|c|c|c|c|}
\hline 19 & $\mathrm{NH}_{2}$ & $\begin{array}{c}\text { 4- } \mathrm{MeO}- \\
\mathrm{C}_{6} \mathrm{H}_{4}\end{array}$ & $\mathrm{H}$ & - & $1^{\mathrm{c}}$ & $>64$ & $>64^{\mathrm{d}}$ & $32(2)^{\mathrm{h}}$ \\
\hline 20 & $\mathrm{NH}_{2}$ & $\mathrm{H}$ & $\begin{array}{c}\mathrm{Si}(t \mathrm{Bu})_{2-} \\
\mathrm{O}_{(\mathrm{C} 11)}\end{array}$ & - & $1^{\mathrm{c}}$ & $>64$ & $>64^{\mathrm{d}}$ & $64(8)^{\mathrm{h}}$ \\
\hline 21 & $\mathrm{NH}_{2}$ & $\mathrm{H}$ & Ac & 16 & $16^{\mathrm{b}}$ & - & $>64(1)^{\mathrm{f}}$ & $8(4)^{g}$ \\
\hline 22 & $\mathrm{NH}_{2}$ & $\mathrm{H}$ & $\begin{array}{c}\mathrm{CO}(4- \\
\left.\mathrm{BrC}_{6} \mathrm{H}_{4}\right)\end{array}$ & 4 & $4^{b}$ & - & $>64(>64)^{\mathrm{f}}$ & $>64 ;(64)^{2}$ \\
\hline
\end{tabular}

${ }^{\mathrm{a}}$ S. aureus DSM-346, ${ }^{\mathrm{b}}$ S. aureus Newman, ${ }^{\mathrm{c}}$ S. aureus DSM-11822, ${ }^{\mathrm{d}}$ P. aeruginosa PA14, ${ }^{\mathrm{e}}$ P. aeruginosa DSM-1128, ${ }^{\mathrm{f}}$ P. aeruginosa PA14 $\mathrm{DmexAB},{ }^{\mathrm{g}}$ E. coli DSM-1116, ${ }^{\mathrm{h}}$ E. coli $\triangle$ TolC. MIC values between brackets were measured in the presence of the outer membrane permeabilizer PMBN (polymyxin B nonapeptide). 


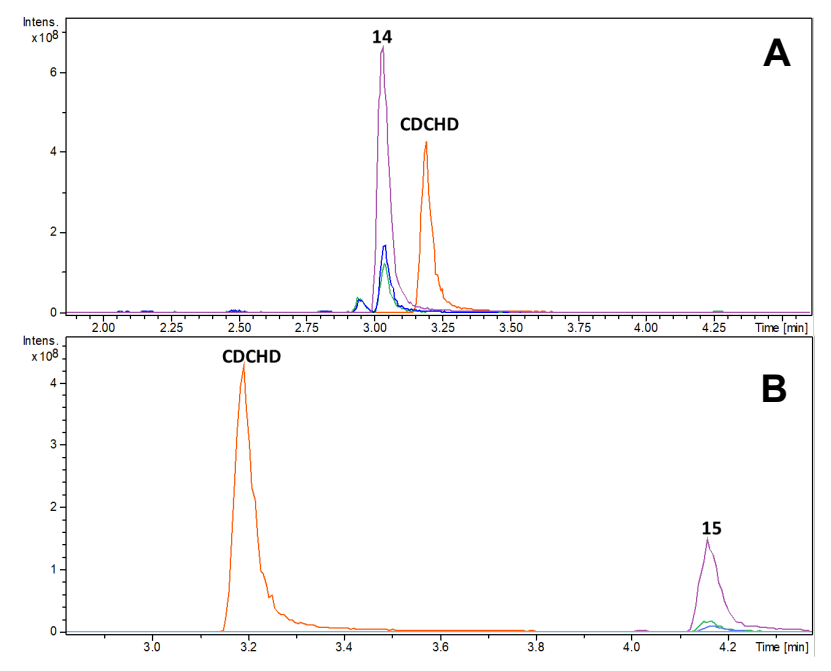

Figure 5: A) Superimposed LC-MS chromatograms of CDCHD in stock solution (red), 21 in stock solution (purple), re-extraction of $\mathbf{2 1}$ from the medium (blue) and re-extraction of $\mathbf{2 1}$ from the E. coli suspension (green); B) superimposed LC-MS chromatograms of CDCHD in stock solution (red), 22 in stock solution (purple), reextraction of $\mathbf{2 2}$ from the medium (blue) and re-extraction of $\mathbf{2 2}$ from the E. coli suspension (green). 


\section{Experimental section}

Microbiological assays. All bacterial indicator strains were obtained from the German Collection of Microorganisms and Cell Cultures (Deutsche Sammlung von Mikroorganismen und Zellkulturen, DSMZ) or were part of the internal strain collection. Minimal inhibitory concentrations (MIC) were determined by microbroth dilution assays. Overnight cultures were diluted in Mueller-Hinton broth $(0.4 \%$ beef extract, $0.15 \%$ starch, 1.75 $\%$ casein hydrolysate, $\mathrm{pH}$ 7.4) to achieve a final inoculum of ca. $5 \times 10^{6} \mathrm{CFU} / \mathrm{mL}$. Serial dilutions of each compound were prepared from $\mathrm{H}_{2} \mathrm{O}$ stocks ( $\mathrm{Na}-\mathrm{CHD} / \mathrm{Na}$ citrate and $\mathrm{Na}-\mathrm{CDCHD} / \mathrm{Na}$ citrate) or $\mathrm{MeOH}$ stocks (all semi-synthetic derivatives) in sterile 96 -well plates. The cell suspension was added and microorganisms were grown for $16-18 \mathrm{~h}$ at 30 or $37{ }^{\circ} \mathrm{C}$. Growth inhibition was assessed by visual inspection and MIC values were determined as the lowest concentration of antibiotic at which no visible growth was observed.

Chemistry. General information. Unless otherwise noted, all reagents were purchased from commercial suppliers and used without further purification.

The starting material CDCHD was produced by fermentation on a gram scale as described before in Lesnik et al., Angew. Chem. Int. Ed. 2015.

All solvents used for workup and purification were of HPLC grade. Moisture-sensitive reactions were performed in dried glassware under argon atmosphere, unless otherwise noted. Preparative RP high-pressure liquid chromatography (HPLC) was performed on a Phenomenex Gemini C18 RP-column 00G-4436-NO, $10 \mu \mathrm{m}$, $110 \mathrm{~A}, 250 \times 10.00 \mathrm{~mm}(5 \mathrm{~mL} / \mathrm{min})$ or on a Phenomenex Gemini C18 RP-column 00G-4435-PO-AX, $5 \mu \mathrm{m}$, $110 \mathrm{~A}, 250 \times 21.20 \mathrm{~mm}(10 \mathrm{~mL} / \mathrm{min})$ or on a Thermo Fisher Scientific BDS Hypersil C18 RP-column 28105259370, $5 \mu \mathrm{m}, 250 \times 30 \mathrm{~mm},(25 \mathrm{~mL} / \mathrm{min})$ or a Macherey-Nagel Nucleosil 100-7 VP C18 RP column715691$1116949,250 \times 40 \mathrm{~mm}$ (from 25 to $50 \mathrm{~mL} / \mathrm{min}$ ) using a Thermo Fisher Scientific Dionex Ultimate 3000 HPLC system. Eluents, gradients and additives are given in parentheses. The product-containing fractions were combined, diluted with milliQ $\mathrm{H}_{2} \mathrm{O}$ (min. 1:1/solvent: $\mathrm{H}_{2} \mathrm{O}$ ), frozen and lyophilized. In some cases, in particular concerning compounds $\mathbf{1 3 - 2 2}$, the products did not differ much in polarity from the starting material and coeluted with it. Considering furthermore the limited amounts of starting material and the moderate-low yields of conversions, we could not avoid the presence of $<10 \%$ impurities. Nuclear Magnetic Resonance (NMR) spectra were recorded on a Bruker Avance III, a Bruker Avance III HD with cryoprobe system, or Bruker Avance Neo $500 \mathrm{MHz}$ with prodigy cryoprobe system. ${ }^{1} \mathrm{H}$ NMR spectra were recorded at $500 \mathrm{MHz}$ and $700 \mathrm{MHz} .{ }^{13} \mathrm{C}$ NMR spectra were recorded at $126 \mathrm{MHz}$ and $176 \mathrm{MHz}$. Chemical shifts are reported in ppm relative to the solvent signal. Multiplicity is indicated as follows: $\mathrm{s}$ (singlet); bs (broad singlet); d (doublet); $\mathrm{t}$ (triplet); q (quartet); $\mathrm{m}$ (multiplet); dd (doublet of doublets), etc. Liquid chromatography-coupled high resolution mass spectrometry (HRMS) data were recorded using a Dionex Ultimate 3000 HPLC system equipped with a DAD detector and a Bruker maXis HD QTOF mass detector with electrospray ionization (ESI) or a Q Exactive Focus (Thermo Scientific) mass spectrometer. 
(4R,4aS,12aS)-3,10,11,12a-Tetrahydroxy-6,9-dimethyl-4-(methylamino)-1,12-dioxo-1,4,4a,5,12,12ahexahydrotetracene-2-carboxamide [1] and $(4 R, 4 \mathrm{a} S, 12 \mathrm{a} S)-4$-(dimethylamino)-3,10,11,12a-tetrahydroxy6,9-dimethyl-1,12-dioxo-1,4,4a,5,12,12a-hexahydrotetracene-2-carboxamide [2] Paraformaldehyde (22 mg) was added to a solution of CDCHD (20 mg, 1 equiv) in methanol $(4 \mathrm{~mL})$ and triethylamine ( $40 \mu \mathrm{L}, 6$ equiv) under nitrogen atmosphere. The resultant mixture was sonicated, followed by the addition of palladium on carbon. The flask was then bubbled with hydrogen for $10 \mathrm{~min}$ and then it was allowed to stir under hydrogen gas balloon pressure at room temperature for $16 \mathrm{~h}$. Reaction was filtered through a pad of celite and the filtrate was evaporated under vacuum. The crude was then purified by preparative HPLC using acetonitrile / water $(0.1 \%$ formic acid) with a gradient from 20 to $90 \%$ of acetonitrile to afford the mono-methylated compound as a yellow solid ( $1 \mathrm{mg}, 4 \%)$ and the dimethylated compound as a yellow solid (1.5 mg, $11 \%)$. Mono-methylated compound [1]: ${ }^{1}$ H NMR (700 MHz, Methanol-d 4$) \delta 7.46(\mathrm{~d}, J=8.6 \mathrm{~Hz}, 1 \mathrm{H}), 7.22(\mathrm{~d}, J=8.7 \mathrm{~Hz}, 1 \mathrm{H}), 3.32(\mathrm{dd}, J=14.6$, $3.5 \mathrm{~Hz}, 1 \mathrm{H}), 3.09$ (dd, $J=14.6,11.8 \mathrm{~Hz}, 1 \mathrm{H}), 3.00$ (dd, $J=11.7,3.4 \mathrm{~Hz}, 1 \mathrm{H}), 2.54$ (s, 3H), 2.36 (s, 3H), 2.34 (s, $3 \mathrm{H})$. The proton at $\mathrm{C} 4$ is not visible because it is hidden by the water peak at $4.87 \mathrm{ppm} .{ }^{13} \mathbf{C}$ NMR (176 MHz, Methanol-d 4 ) $\delta 176.5,175.1,151.8,150.7,134.4,130.1,130.0,124.4,119.2,118.8,117.3,116.3,92.6$, 85.1, 64.9, 56.54, 26.8, 25.4, 16.0, 16.0, 12.8. HRMS (ESI) calculated for $\mathrm{C}_{22} \mathrm{H}_{23} \mathrm{~N}_{2} \mathrm{O}_{7}(\mathrm{M}+\mathrm{H}) 427.1500$, found 427.1493. Dimethylated compound [2]: ${ }^{1}$ H NMR (700 MHz, Methanol-d 4$) \delta 7.47(\mathrm{~d}, J=8.6 \mathrm{~Hz}, 1 \mathrm{H}), 7.23(\mathrm{~d}, J$ $=8.7 \mathrm{~Hz}, 1 \mathrm{H}), 3.31(\mathrm{dd}, J=13.0,2.0 \mathrm{~Hz}, 1 \mathrm{H}), 3.08-3.00(\mathrm{~m}, 2 \mathrm{H}), 2.95(\mathrm{~s}, 3 \mathrm{H}), 2.53(\mathrm{~s}, 3 \mathrm{H}), 2.36(\mathrm{~s}, 3 \mathrm{H}), 2.32$ (s, 3H). The proton at $\mathrm{C} 4$ is not visible because it is hidden by the water peak at $4.87 \mathrm{ppm} .{ }^{13} \mathbf{C}$ NMR (176 MHz, Methanol-d 4 ) $\delta 174.9,174.0,151.6,150.7,134.3,134.1,130.1,129.9,124.1,119.2,118.5,117.2,116.2$, 92.5, 85.2, 66.5, 54.5, 30.0, 26.6, 15.9, 15.8, 12.6. HRMS (ESI) calculated for $\mathrm{C}_{23} \mathrm{H}_{25} \mathrm{~N}_{2} \mathrm{O}_{7}(\mathrm{M}+\mathrm{H}) 441.1656$, found 441.1662 .

\section{Benzyl((1R,4aS,12aS)-3-carbamoyl-2,4a,6,7-tetrahydroxy-8,11-dimethyl-4,5-dioxo-1,4,4a,5,12,12a-}

hexahydrotetracen-1-yl)carbamate [3] An aqueous solution of $\mathrm{NaHCO}_{3}(7.5 \mathrm{mg}, 7$ equiv) was slowly added to a vigorously stirred solution of CDCHD (5 mg, 1 equiv) and benzoyl chloride $(10 \mu \mathrm{L})$ in THF/water 5:1 $(3 \mathrm{~mL})$. The reaction mixture was stirred at RT for 30 min and then acidified to $\mathrm{pH} 2$ with a $5 \mathrm{~N} \mathrm{HCl}$ solution. The reaction mixture was then extracted with methylene chloride $(2 \mathrm{x})$, and the combined organic layers were dried over sodium sulfate, filtered and evaporated under vacuum. The crude compound was purified by preparative HPLC using acetonitrile / water ( $0.1 \%$ formic acid) with a gradient from 20 to $90 \%$ of acetonitrile to afford the pure product as a yellow solid (2 mg, 30\%). ${ }^{1} \mathbf{H}$ NMR (500 MHz, Methanol-d 4$) \delta 7.53-7.30(\mathrm{~m}, 7 \mathrm{H}), 5.38(\mathrm{~d}, J$ $=3.2 \mathrm{~Hz}, 1 \mathrm{H}), 5.21(\mathrm{~s}, 2 \mathrm{H}), 3.44-3.36(\mathrm{~m}, 1 \mathrm{H}), 3.01(\mathrm{dt}, J=12.4,4.9 \mathrm{~Hz}, 1 \mathrm{H}), 2.78-2.67(\mathrm{~m}, 1 \mathrm{H}), 2.36(\mathrm{~d}, J=$ $4.8 \mathrm{~Hz}, 3 \mathrm{H}), 2.34$ (s, 3H). ${ }^{13} \mathbf{C}$ NMR (126 MHz, Methanol-d 4 ) $\delta$ 175.1, 164.2, 159.2, 156.6, 139.0, 138.2, 136.3, $130.9,129.5,129.1,129.0,123.7,120.9,115.6,113.0,109.9,67.9,43.5,26.7,15.6,14.2$. HRMS (ESI) calculated for $\mathrm{C}_{29} \mathrm{H}_{27} \mathrm{~N}_{2} \mathrm{O}_{9}(\mathrm{M}+\mathrm{H})$ 547.1711, found 547.1714.

\section{Ethyl((1R,4aS,12aS)-3-carbamoyl-2,4a,6,7-tetrahydroxy-8,11-dimethyl-4,5-dioxo-1,4,4a,5,12,12a-}

hexahydrotetracen-1-yl)carbamate [4] Ethyl chloroformate (5.2 $\mu \mathrm{L}, 1.5$ equiv) and DIPEA (32 $\mu \mathrm{L}, 5$ equiv) were added to a solution of CDCHD (15 mg, 1 equiv) in THF $(3 \mathrm{~mL})$. The resulting mixture was stirred at room 
temperature overnight. After concentration under vacuum, the reaction mixture was extracted with EtOAc and the organic layer was washed with saturated aqueous $\mathrm{NaCl}$ solution dried over sodium sulfate, filtered and evaporated under vacuum. The crude compound was purified by preparative HPLC using Biphenyl column, $\mathrm{MeOH} /$ water (0.05\% formic acid) with a gradient from 15 to $95 \%$ of $\mathrm{MeOH}$ to afford the pure product as a yellow solid (4.3 mg, 24\%). ${ }^{1}$ H NMR (500 MHz, Acetone-d f $_{\text {) }} \delta 10.11$ (br s, 1H), $9.27(\mathrm{~s}, 1 \mathrm{H}), 8.14(b r \mathrm{~s}, 1 \mathrm{H})$, $7.51(\mathrm{~d}, J=8 \mathrm{~Hz}, 1 \mathrm{H}), 7.36(\mathrm{~d}, J=8.5 \mathrm{~Hz}, 1 \mathrm{H}), 6.86(b r \mathrm{~s}, 1 \mathrm{H}), 6.12(b r \mathrm{~s}, 1 \mathrm{H}), 5.53(b r \mathrm{~s}, 1 \mathrm{H}), 4.13(\mathrm{q}, J=7.0$ $\mathrm{Hz}, 2 \mathrm{H}), 3.55(b r \mathrm{~d}=17.0 \mathrm{~Hz}, 1 \mathrm{H}), 3.06(b r \mathrm{~s}, 1 \mathrm{H}), 2.98-2.71(\mathrm{~m}, 1 \mathrm{H}), 2.36(\mathrm{~s}, 3 \mathrm{H}), 2.29(\mathrm{~s}, 3 \mathrm{H}), 1.24(\mathrm{t}, J=7.0$ Hz, 3H). ${ }^{13}$ C NMR (126 MHz, Acetone-d (1) $_{\text {S }}$ 196.3, 190.4, 175.0, 164.2, 157.8, 156.4, 138.7, 136.2, 131.0, 123.3, 120.5, 115.3, 112.7, 109.5, 98.7, 79.4, 61.4, 53.5, 43.1, 26.5, 15.5, 15.0, 14.2. HRMS (ESI) calculated for $\mathrm{C}_{24} \mathrm{H}_{25} \mathrm{~N}_{2} \mathrm{O}_{9}(\mathrm{M}+\mathrm{H}) 485.1560$, found 485.1531 .

(4R,4aS,12aS)-4-(2,5-Dioxo-2,5-dihydro-1H-pyrrol-1-yl)-3,10,11,12a-tetrahydroxy-6,9-dimethyl-1,12-dioxo1,4,4a,5,12,12a-hexahydrotetracene-2-carboxamide [5] Maleic anhydride (16 mg, 3 equiv) was added to a solution of CDCHD (22 mg, 1 equiv) in acetic acid $(4 \mathrm{~mL})$. The resulting mixture was stirred at $100{ }^{\circ} \mathrm{C}$ for 2 days. After cooling, the reaction mixture was extracted with EtOAc, and the organic layer was washed with saturated aqueous $\mathrm{NaCl}$ solution, dried over sodium sulfate, filtered and evaporated under vacuum. The crude compound was purified by preparative HPLC using Biphenyl column, $\mathrm{MeOH} /$ water $(0.05 \%$ formic acid $)$ with a gradient from 50 to $95 \%$ of $\mathrm{MeOH}$ to afford the pure product (4 mg, 15\%). ${ }^{1} \mathbf{H}$ NMR (500 MHz, Acetone-d $\left.\mathbf{6}\right) \delta$ $10.19(b r \mathrm{~s}, 1 \mathrm{H}), 9.63(\mathrm{~s}, 1 \mathrm{H}), 8.46(b r \mathrm{~s}, 1 \mathrm{H}), 7.56(\mathrm{~d}, J=8.5 \mathrm{~Hz}, 1 \mathrm{H}), 7.42(\mathrm{~d}, J=8.0 \mathrm{~Hz}, 1 \mathrm{H}), 6.98(\mathrm{~s}, 2 \mathrm{H}), 5.89$ ( $b r \mathrm{~s}, 1 \mathrm{H}), 4.88(b r \mathrm{~s}, 1 \mathrm{H}), 3.41(b r \mathrm{~s}, 1 \mathrm{H}), 3.33(\mathrm{dd}, J=4.5 ; 17.0 \mathrm{~Hz}, 1 \mathrm{H}), 3.10(\mathrm{~d}, J=17.0 \mathrm{~Hz}, 1 \mathrm{H}), 2.33(\mathrm{~s}, 3 \mathrm{H})$, 2.31 (s, 3H). ${ }^{13} \mathbf{C}$ NMR (126 MHz, Acetone-d $)$ ) $\delta$ 174.5, 171.1, 166.8, 156.8, 139.2, 136.4, 136.0, 135.2, 129.6, 120.8, 120.8, 115.6, 112.8, 109.1, 76.8, 52.4, 41.6, 24.7, 15.5, 14.4. HRMS (ESI) calculated for $\mathrm{C}_{25} \mathrm{H}_{21} \mathrm{~N}_{2} \mathrm{O}_{9}$ $(\mathrm{M}+\mathrm{H})$ 493.1247, found 493.1218.

\section{(4R,4aS,12aS)-4-(1,3-Dioxoisoindolin-2-yl)-3,10,11,12a-tetrahydroxy-6,9-dimethyl-1,12-dioxo-}

1,4,4a,5,12,12a-hexahydrotetracene-2-carboxamide [6] To CDCHD (17 mg, 1 equiv), phthalic anhydride (31 mg, 5 equiv) and DIPEA ( $36 \mu \mathrm{L}, 5$ equiv) were added. The resulting mixture was heated at $120^{\circ} \mathrm{C}$ for $1 \mathrm{~h}$. After cooling, the reaction mixture was extracted with EtOAc, and the organic layer was washed with saturated aqueous $\mathrm{NaCl}$ solution, dried over sodium sulfate, filtered and evaporated under vacuum. The crude compound was dissolved in $\mathrm{MeCN}$, filtered and purified by preparative HPLC using Biphenyl column, $\mathrm{MeOH} /$ water (0.05 $\%$ formic acid) with a gradient from 70 to $95 \%$ of $\mathrm{MeOH}$ to afford the pure product $(4.0 \mathrm{mg}, 18 \%) .{ }^{1} \mathbf{H}$ NMR (500 MHz, Acetone-d $\left.)_{6}\right) \delta 10.19(b r \mathrm{~s}, 1 \mathrm{H}), 9.66(\mathrm{~s}, 1 \mathrm{H}), 8.49(b r \mathrm{~s}, 1 \mathrm{H}), 8.05-7.79(\mathrm{~m}, 4 \mathrm{H}), 7.57(\mathrm{~d}, J=8.0 \mathrm{~Hz}$, $1 \mathrm{H}), 7.43(\mathrm{~d}, J=7.5 \mathrm{~Hz}, 1 \mathrm{H}), 5.92(b r \mathrm{~s}, 1 \mathrm{H}), 5.09(b r \mathrm{~s}, 1 \mathrm{H}), 3.57(b r \mathrm{~s}, 1 \mathrm{H}), 3-44-3.16(\mathrm{~m}, 2 \mathrm{H}), 2.32(\mathrm{~s}, 3 \mathrm{H})$, 2.31 (s, 3H). ${ }^{13}$ C NMR (126 MHz, Acetone-d 6 ) $\delta$ 174.6, 168.2, 166,6, 156.8, 139.2, 136.4, 135.6, 135.5, 132.9, 132.5, 129.8, 124.4, 124.1, 120.8, 115.7, 112.8, 109.2, 76.9, 52.8, 41.5, 24.8, 15.5, 14.4. HRMS (ESI) calculated for $\mathrm{C}_{29} \mathrm{H}_{23} \mathrm{~N}_{2} \mathrm{O}_{9}(\mathrm{M}+\mathrm{H})$ 543.1404, found 543.1376. 
(4R,4aS,12a $S)$-4-Acetamido-3,10,11,12a-tetrahydroxy-6,9-dimethyl-1,12-dioxo-1,4,4a,5,12,12a-

hexahydrotetracene-2-carboxamide [7] To a solution of CDCHD (10 mg, 1 equiv) and acetyl chloride ( $3 \mu \mathrm{L}$, 1.5 equiv) in THF $(1 \mathrm{~mL})$ was added dropwise an aqueous solution of sodium carbonate $(100 \mu \mathrm{L}, 0.7 \mathrm{M})$. The reaction mixture was stirred at room temperature for $30 \mathrm{~min}$. It was then acidified to $\mathrm{pH} 2$ with a $5 \mathrm{~N} \mathrm{HCl}$ solution and diluted with methylene chloride $(5 \mathrm{~mL})$. The organic layer was separated, dried over sodium sulfate and evaporated under vacuum. Obtained crude compound was purified by preparative HPLC using acetonitrile / water $(0.1 \%$ formic acid) with a gradient from 20 to $90 \%$ of acetonitrile to afford the pure compound as a orange solid (5 mg, 38\%). ${ }^{1} \mathbf{H}$ NMR (700 MHz, Methanol-d 4$) \delta 7.47$ (d, $\left.J=8.5 \mathrm{~Hz}, 1 \mathrm{H}\right), 7.32$ (d, $\left.J=8.4 \mathrm{~Hz}, 1 \mathrm{H}\right), 3.39$ (dd, $J=17.3,5.5 \mathrm{~Hz}, 1 \mathrm{H}), 3.02-2.95(\mathrm{~m}, 1 \mathrm{H}), 2.75$ (dd, $J=17.1,12.9 \mathrm{~Hz}, 1 \mathrm{H}), 2.36(\mathrm{~s}, 3 \mathrm{H}), 2.33(\mathrm{~s}, 3 \mathrm{H}), 2.17$ (s, 3H). ${ }^{13}$ C NMR (176 MHz, Methanol-d 4 ) $\delta$ 175.2, 173.8, 164.1, 156.5, 138.9, 136.3, 130.8, 123.6, 121.0, 115.6, 112.9, 109.9, 98.7, 43.0, 26.7, 22.6, 15.6, 14.2. HRMS (ESI) calculated for $\mathrm{C}_{23} \mathrm{H}_{23} \mathrm{~N}_{2} \mathrm{O}_{8}(\mathrm{M}+\mathrm{H}) 455.1449$, found 455.1453 .

\section{(4R,4aS,12aS)-4-(3-Aminopropanamido)-3,10,11,12a-tetrahydroxy-6,9-dimethyl-1,12-dioxo-}

1,4,4a,5,12,12a-hexahydrotetracene-2-carboxamide [8] Step 1: Amide coupling To a stirred solution of CDCHD (41 mg, $0.1 \mathrm{mmol}, 1$ equiv) and $N$-Boc- $\beta$-alanine (19 mg, $0.1 \mathrm{mmol}, 1$ equiv) in EtOAc $(0.5 \mathrm{~mL})$ and pyridine $(0.3 \mathrm{~mL})$, propylphosphonic anhydride (T3P) $50 \%$ solution in EtOAc $(0.13 \mathrm{~mL}, 2$ equiv) was added. The reaction was stirred at $40{ }^{\circ} \mathrm{C}$ for $17 \mathrm{~h}$. The mixture was poured onto water $(10 \mathrm{~mL})$, acidified by addition of $\mathrm{HCl}$ $(1 \mathrm{M})$ to $\mathrm{pH} 5-6$ and extracted with EtOAc $(10 \mathrm{~mL} \times 2)$. The combined organic layers were dried over sodium sulfate, and the solvent was removed under reduced pressure. The crude material was purified by preparative HPLC using acetonitrile $(0.05 \%$ formic acid $)$ / water $(0.05 \%$ formic acid) as eluent with a gradient from 10 to $90 \%$ of acetonitrile to afford the pure product (13 mg, 22\%). HRMS (ESI) calculated for $\mathrm{C}_{29} \mathrm{H}_{34} \mathrm{~N}_{3} \mathrm{O}_{10}(\mathrm{M}+\mathrm{H}$ ) 584.2244, found 584.2204. Step 2: Boc-deprotection To a stirred solution of $8 \mathbf{8 a}$ (12 $\mathrm{mg}, 0.02 \mathrm{mmol}, 1$ equiv) in DCM $(6 \mathrm{~mL})$, TFA $(1 \mathrm{~mL})$ was added. The reaction was stirred at room temperature for $1 \mathrm{~h}$. Solvent was removed under reduced pressure, and the residue was purified by preparative HPLC using acetonitrile $(0.05 \%$ formic acid) / water $(0.05 \%$ formic acid) as eluent with a gradient from 10 to $60 \%$ of acetonitrile to afford the pure product as yellow solid (2 mg, 21\%). ${ }^{1}$ H NMR (500 MHz, DMSO-d $\left.\mathbf{~}_{6}\right) \delta 9.23(\mathrm{~s}, 1 \mathrm{H}), 8.50$ (s, 1H), 8.31 (s, 1H), $7.14(\mathrm{~d}, J=8.1 \mathrm{~Hz}, 1 \mathrm{H}), 6.77(\mathrm{~d}, J=7.9 \mathrm{~Hz}, 1 \mathrm{H}), 5.98(\mathrm{~s}, 1 \mathrm{H}), 5.31(\mathrm{~s}, 1 \mathrm{H}), 3.41-2.99(\mathrm{~m}, 6 \mathrm{H}), 2.65(\mathrm{~m}$, 2H), 2.10 (s, 6H). HRMS (ESI) calculated for $\mathrm{C}_{24} \mathrm{H}_{26} \mathrm{~N}_{3} \mathrm{O}_{8}(\mathrm{M}+\mathrm{H}) 484.1712$, found 484.1691.

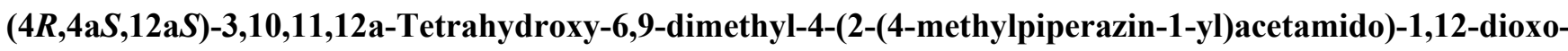
1,4,4a,5,12,12a-hexahydrotetracene-2-carboxamide [9] To a stirred mixture of 2-(4-methylpiperazin-1yl)acetic acid (10 mg, $0.063 \mathrm{mmol}, 1$ equiv) in THF ( $3 \mathrm{~mL})$, thionyl chloride (12 $\mathrm{mg}, 0.1 \mathrm{mmol}, 1.6$ equiv) was added followed by DMF ( 1 drop) under nitrogen atmosphere. The reaction was stirred at $60{ }^{\circ} \mathrm{C}$ for $1 \mathrm{~h}$. Volatiles were removed under reduced pressure, and the yellow residue was directly added to a stirred solution of CDCHD (21 mg, $0.05 \mathrm{mmol}, 0.8$ equiv) in $N$-methyl-2-pyrrolidone (NMP) $(1 \mathrm{~mL})$. The reaction mixture was further stirred at room temperature under nitrogen atmosphere for $16 \mathrm{~h}$. The crude material was purified by preparative HPLC using acetonitrile $(0.05 \%$ formic acid $) /$ water $(0.05 \%$ formic acid $)$ as eluent with a gradient from 10 to 16 
90\% of acetonitrile to afford the pure product ( $2 \mathrm{mg}, 7 \%$ ). ${ }^{1} \mathbf{H}$ NMR (700 MHz, DMSO-d $\left.\mathbf{6}\right) \delta 7.25$ (s, $\left.1 \mathrm{H}\right), 7.12$ $(\mathrm{s}, 1 \mathrm{H}), 7.02(\mathrm{~s}, 1 \mathrm{H}), 6.83(\mathrm{~s}, 1 \mathrm{H}), 6.69(\mathrm{~s}, 1 \mathrm{H}), 5.44-5.32(\mathrm{~m}, 3 \mathrm{H}), 3.28(\mathrm{~s}, 2 \mathrm{H}), 3.03(\mathrm{~m}, 1 \mathrm{H}), 2.88(\mathrm{~m}, 1 \mathrm{H}), 2.60$ $(\mathrm{m}, 2 \mathrm{H}), 2.52(\mathrm{~m}, 4 \mathrm{H}), 2.40(\mathrm{~m}, 4 \mathrm{H}), 2.18-2.14(\mathrm{~m}, 9 \mathrm{H})$. HRMS (ESI) calculated for $\mathrm{C}_{28} \mathrm{H}_{33} \mathrm{~N}_{4} \mathrm{O}_{8}(\mathrm{M}+\mathrm{H})$ 553.2298 , found 553.2276 .

(4R,4aS,12aS)-4-Acrylamido-3,10,11,12a-tetrahydroxy-6,9-dimethyl-1,12-dioxo-1,4,4a,5,12,12ahexahydrotetracene-2-carboxamide [10] In a heat-dried Schlenk tube, CDCHD (33 mg, 0.08 mmol, 1 equiv) was dissolved in $N$-methyl-2-pyrrolidone $(1.7 \mathrm{~mL})$. The reaction mixture was cooled down to $0{ }^{\circ} \mathrm{C}$, and acryloyl chloride (7.7 $\mu \mathrm{L}, 0.095 \mathrm{mmol}, 1.2$ equiv) was added. The resulting brown reaction mixture was kept stirring and was slowly left to warm up to room temperature. After $18 \mathrm{~h}$, water $(2 \mathrm{~mL})$ and EtOAc $(5 \mathrm{~mL})$ was added. The organic layer was separated and dried over sodium sulfate, filtered, and volatiles were removed on a rotary evaporator. The crude was purified by preparative HPLC using $20-100 \%$ gradient (acetonitrile $(0.1 \%$ formic acid) in water ( $0.1 \%$ formic acid)). After removing water and acetonitrile from the pure fractions under vacuum, the yellow product was obtained (2 mg, 5\%). ${ }^{1} \mathbf{H}$ NMR (500 MHz, DMSO-d $)$ ) $\delta 9.22(\mathrm{~s}, 2 \mathrm{H}), 8.66(\mathrm{~d}, J=8.7 \mathrm{~Hz}$, 1H), 7.50 (d, $J=8.4 \mathrm{~Hz}, 1 \mathrm{H}), 7.30$ (d, $J=8.2 \mathrm{~Hz}, 1 \mathrm{H}), 7.13$ (s, 1H), 6.46 (dd, $J=17.1,10.3 \mathrm{~Hz}, 1 \mathrm{H}), 6.21(\mathrm{dd}, J$ $=17.1,1.8 \mathrm{~Hz}, 1 \mathrm{H}), 5.72(\mathrm{dd}, J=10.3,1.8 \mathrm{~Hz}, 1 \mathrm{H}), 5.61(\mathrm{~s}, 1 \mathrm{H}), 3.33-3.02(\mathrm{~m}, 2 \mathrm{H}), 2.88-2.76(\mathrm{~m}, 1 \mathrm{H}), 2.76$ - 2.65 (m, 1H), 2.32 (s, 3H), 2.26 (s, 3H). ${ }^{13}$ C NMR (126 MHz, DMSO-d $)$ ) $\delta$ 173.5, 165.6, 137.5, 135.5, 131.7, 130.7, 126.8, 119.3, 114.6, 112.3, 112.1, 109.1, 98.2, 42.0, 26.4, 15.8, 14.3. HRMS (ESI) calculated for $\mathrm{C}_{24} \mathrm{H}_{23} \mathrm{~N}_{2} \mathrm{O}_{8}(\mathrm{M}+\mathrm{H})$ 467.1454, found 467.1430 .

\section{(4R,4aS,12aS)-3,10,11,12a-Tetrahydroxy-4-(4-methoxybenzamido)-6,9-dimethyl-1,12-dioxo-}

1,4,4a,5,12,12a-hexahydrotetracene-2-carboxamide [11] 4-Methoxybenzoyl chloride (6 $\mu \mathrm{L}, 1$ equiv.) and DIPEA ( $25 \mu \mathrm{L}, 5$ equiv.) were added to a solution of CDCHD (12 mg, 1 equiv.) in THF ( $3 \mathrm{~mL})$. The resulting mixture was stirred at room temperature overnight. After concentration under vacuum, the reaction mixture was extracted with EtOAc, and the organic layer was washed with saturated aqueous $\mathrm{NaCl}$ solution, dried over sodium sulfate, filtered and evaporated under vacuum. The crude compound was purified by preparative HPLC using Biphenyl column, $\mathrm{MeOH} /$ water with a gradient from 15 to $95 \%$ of $\mathrm{MeOH}$ to afford the pure product (5.0 mg, 31\%). ${ }^{1}$ H NMR (500 MHz, Methanol-d 4$) \delta 7.92(\mathrm{~d}, J=8.5 \mathrm{~Hz}, 2 \mathrm{H}), 7.41$ (d, $\left.J=7.0 \mathrm{~Hz}, 1 \mathrm{H}\right), 7.26(\mathrm{~d}, J=$ $6.5 \mathrm{~Hz}, 1 \mathrm{H}), 7.02$ (d, $J=8.5 \mathrm{~Hz}, 2 \mathrm{H}), 3.87$ (s, 3H), 3.41-3.25 (m, 1H), 3.16-3.04 (m, 1H), 2.92-2.76 (m, 1H), 2.29 (s, 3H), 2.28 (s, 3H). ${ }^{13}$ C NMR (126 MHz, Methanol-d 4 ) $\delta$ 173.7, 168.9, 162.8, 155.3, 137.6, 134.8, 129.7, $129.2,126.1,122.0,119.4,114.1,113.4,111.6,108.7,78.2,67.8,54.6,41.5,25.6,14.2,12.8$. HRMS (ESI) calculated for $\mathrm{C}_{29} \mathrm{H}_{27} \mathrm{~N}_{2} \mathrm{O}_{9}(\mathrm{M}+\mathrm{H})$ 547.1717, found 547.1687.

\section{(4R,4aS,12aS)-3,10,11,12a-Tetrahydroxy-6,9-dimethyl-4-(methylsulfonamido)-1,12-dioxo-1,4,4a,5,12,12a-}

hexahydrotetracene-2-carboxamide [12] An aqueous solution of $\mathrm{NaHCO}_{3}$ (15 mg, 7 equiv) was slowly added to a vigorously stirred solution of CDCHD (10 mg, 1 equiv) and methanesulfonyl chloride (10 $\mu \mathrm{L})$ in THF/water 5:1 (3 mL). The reaction mixture was stirred at rtfor $30 \mathrm{~min}$ and then acidified to $\mathrm{pH} 2$ with $\mathrm{HCl}$ solution $(5 \mathrm{~N})$. The reaction mixture was then extracted with methylene chloride $(2 \mathrm{x})$, and the combined organic layers were 
dried over sodium sulfate, filtered and evaporated under vacuum. The crude compound was purified by preparative HPLC using acetonitrile / water ( $0.1 \%$ formic acid) with a gradient from 20 to $90 \%$ of acetonitrile to afford the pure product as an orange solid (1.8 mg, $16 \%) .{ }^{1} \mathbf{H}$ NMR (500 MHz, Methanol-d $\left.{ }_{4}\right) \delta 7.47(\mathrm{~d}, J=8.7$ $\mathrm{Hz}, 1 \mathrm{H}), 7.35$ (d, $J=8.5 \mathrm{~Hz}, 1 \mathrm{H}), 5.05$ (d, $J=4.3 \mathrm{~Hz}, 1 \mathrm{H}), 3.47$ (dd, $J=17.4,5.3 \mathrm{~Hz}, 1 \mathrm{H}), 3.15$ (s, $3 \mathrm{H}), 2.98-$ $2.89(\mathrm{~m}, 1 \mathrm{H}), 2.66(\mathrm{dd}, J=17.8,12.5 \mathrm{~Hz}, 1 \mathrm{H}), 2.37$ (s, 3H), 2.31 (s, 3H). ${ }^{13} \mathbf{C}$ NMR (126 MHz, Methanol-d 4$) \delta$ 175.3, 164.4, 156.8, 139.2, 136.5, 130.9, 123.9, 121.2, 115.8, 113.1, 110.1, 98.6, 45.5, 41.6, 26.6, 15.7, 14.3. HRMS (ESI) calculated for $\mathrm{C}_{22} \mathrm{H}_{23} \mathrm{~N}_{2} \mathrm{O}_{9} \mathrm{~S}(\mathrm{M}+\mathrm{H}) 491.1119$, found 491.1123 .

(4R,4aS,12aS)-4-Amino-7-fluoro-3,10,11,12a-tetrahydroxy-6,9-dimethyl-1,12-dioxo-1,4,4a,5,12,12a-

hexahydrotetracene-2-carboxamide [13] An aqueous solution of sodium bicarbonate was slowly added to the solution of CDCHD (50 mg, 1 equiv) and $\mathrm{Fmoc}-\mathrm{Cl}$ (37.5 mg, 1.2 equiv). The reaction was stirred at room temperature for $30 \mathrm{~min}$ and then acidified to $\mathrm{pH} 6$ by addition of $\mathrm{HCl}$ solution $(6 \mathrm{~N})$ and extracted with ethyl acetate $(2 \times 5 \mathrm{~mL})$. After drying the combined organic layers over sodium sulfate, volatiles were removed under vacuum. The crude compound was then suspended in methanol $(3 \mathrm{~mL})$, and water was added $(1 \mathrm{~mL})$. The product started to appear as a dark brown precipitate appeared and was subsequently filtered. The pure compound was obtained in $27 \%$ yield $(41 \mathrm{mg}$ ). To a solution of Fmoc-protected CDCHD (40 mg, 1 equiv) in 1,2dichloroethane $(8 \mathrm{~mL})$, was added $\mathrm{XeF}_{2}\left(43 \mathrm{mg}, 4\right.$ equiv). The mixture was then stirred at $35^{\circ} \mathrm{C}$ for $3 \mathrm{~h}$. Water $(5$ $\mathrm{mL}$ ) was added, and the reaction mixture was stirred for an additional $10 \mathrm{~min}$. The organic layer was then separated, dried over sodium sulfate and concentrated under reduced pressure. The crude compound was purified by preparative HPLC using acetonitrile/ water $(0.1 \% \mathrm{HCOOH})$ with a 10 to $90 \%$ gradient to afford the pure compound ( $3 \mathrm{mg}, 6 \%)$. A solution of piperidine in DMF (2\%) was added to the Fmoc-protected fluorinated CDCHD (7 mg), and the reaction mixture was stirred at room temperature for 1 hour. Then it was directly injected in a preparative HPLC and purified using acetonitrile/ water $(0.1 \%$ TFA) from $10 \%$ to $90 \%$ of acetonitrile to afford the pure compound as an orange solid (1.5 mg, $26 \%$ ). ${ }^{1} \mathbf{H}$ NMR (700 MHz, Methanol-d 4 ) $\delta$ $7.26(\mathrm{~d}, J=14.8 \mathrm{~Hz}, 1 \mathrm{H}), 4.87$ (d, $J=4.5 \mathrm{~Hz}, 1 \mathrm{H}), 3.38$ (dd, $J=17.1,5.4 \mathrm{~Hz}, 1 \mathrm{H}), 3.16-3.09$ (m, 1H), 2.79 (dd, $J=17.1,12.7 \mathrm{~Hz}, 1 \mathrm{H}), 2.54(\mathrm{~d}, J=6.9 \mathrm{~Hz}, 3 \mathrm{H}), 2.30$ (s, 3H). ${ }^{13} \mathbf{C}$ NMR (176 MHz, Methanol-d 4 ) $\delta 201.0,174.9$, 164.2, 163.3, 154.3, 153.3, 152.9, 130.8, 127.2, 127.1, 122.7, 122.6, 122.2, 114.2, 110.1, 78.6, 54.3, 41.6, 26.2, 17.2, 17.1, 15.6. ${ }^{19} \mathrm{~F}$ NMR (471 MHz, Methanol-d 4 ) $\delta-77.0$ (TFA), -155.0. HRMS (ESI) calculated for $\mathrm{C}_{21} \mathrm{H}_{20} \mathrm{FN}_{2} \mathrm{O}_{7}(\mathrm{M}+\mathrm{H})$ 431.1249, found 431.1256. Other procedure for preparing [13]: Selectfluor ${ }^{\circledR}(20 \mathrm{mg}, 0.056$ mmol, 1 equiv) was added as a solid to a solution of $\mathrm{HCOOH}$ salt of CDCHD ( $25 \mathrm{mg}, 0.055 \mathrm{mmol}, 1$ equiv) in $\mathrm{MeCN}(1.5 \mathrm{~mL})$ and allowed to stir for $1 \mathrm{~h}$ at room temperature. The reaction mixture was then evaporated and purified by preparative HPLC acetonitrile / water ( $0.1 \%$ formic acid) with a gradient from 10 to $90 \%$ of acetonitrile to afford the pure product (3.9 mg, 15\%). NMR and HRMS data are consistent with the previous description.

\section{(4R,4aS,12aS)-4-Amino-7-chloro-3,10,11,12a-tetrahydroxy-6,9-dimethyl-1,12-dioxo-1,4,4a,5,12,12a-}

hexahydrotetracene-2-carboxamide [14] $N$-chlorosuccinimide (5 mg, 1.5 equiv) was added to a solution of CDCHD (10 mg, 1 equiv) in trifluoroacetic acid $(1 \mathrm{~mL})$. The resultant mixture was stirred at room temperature 18 
for $30 \mathrm{~min}$. Solvent was removed under flow of nitrogen and the crude was then purified by preparative HPLC using acetonitrile / water ( $0.1 \%$ TFA) with a gradient from 20 to $90 \%$ of acetonitrile to afford the pure product as an orange solid (2 mg, 28\%). ${ }^{1}$ H NMR (700 MHz, DMSO-d $\left.{ }_{6}\right) \delta 9.56(\mathrm{~s}, 1 \mathrm{H}), 9.35$ (s, 1H), 8.62 (s, 2H), 7.64 (s, $1 \mathrm{H}), 4.72(\mathrm{~d}, J=4.0 \mathrm{~Hz}, 1 \mathrm{H}), 3.25(\mathrm{dd}, J=17.4,5.2 \mathrm{~Hz}, 1 \mathrm{H}), 3.10-3.04(\mathrm{~m}, 1 \mathrm{H}), 2.70(\mathrm{dd}, J=17.2,12.9 \mathrm{~Hz}$, 1H), 2.59 (s, 3H), 2.22 (s, 3H). ${ }^{13}$ C NMR (176 MHz, DMSO-d $) \delta$ 190.5, 190.4, 189.2, 172.6, 157.9, 157.7, 138.3, 133.9, 132.4, 120.7, 114.1, 108.6, 96.7, 76.9, 52.1, 48.6, 25.5, 19.0, 14.9. HRMS (ESI) calculated for $\mathrm{C}_{21} \mathrm{H}_{20} \mathrm{ClN}_{2} \mathrm{O}_{7}(\mathrm{M}+\mathrm{H})$ 447.0953, found 447.0917.

$(4 R, 4 \mathrm{a} S, 12 \mathrm{a} S)$-4-Amino-7-bromo-3,10,11,12a-tetrahydroxy-6,9-dimethyl-1,12-dioxo-1,4,4a,5,12,12a-

hexahydrotetracene-2-carboxamide [15] $N$-bromosuccinimide (19 $\mathrm{mg}, 2$ equiv) was added to a solution of CDCHD (30 mg, 1 equiv) in trifluoroacetic acid $(2.4 \mathrm{~mL}$ ). The resulting mixture was stirred at room temperature for $30 \mathrm{~min}$. Solvent was removed under flow of nitrogen, and the crude was then purified by preparative HPLC using acetonitrile / water (0.1\%TFA) with a gradient of acetonitrile (10 to $90 \%)$ to afford the pure product as an orange solid (3.5 mg, 17\%). ${ }^{1}$ H NMR (500 MHz, Methanol-d 4$) \delta 7.83(\mathrm{~s}, 1 \mathrm{H}), 3.15(\mathrm{dt}, J=12.6,4.9 \mathrm{~Hz}, 1 \mathrm{H})$, $2.78(\mathrm{dd}, J=17.3,13.1 \mathrm{~Hz}, 1 \mathrm{H}), 2.69$ (s, 3H), 2.27 (s, 3H). ${ }^{13}$ C NMR (126 MHz, Methanol-d 4 ) $\delta$ 200.8, 174.9, 157.1, 143.9, 137.4, 133.0, 124.7, 123.2, 115.8, 110.0, 108.2, 97.7, 78.6, 54.2, 41.7, 26.7, 20.6, 15.3. HRMS (ESI) calculated for $\mathrm{C}_{21} \mathrm{H}_{20} \mathrm{BrN}_{2} \mathrm{O}_{7}(\mathrm{M}+\mathrm{H})$ 491.0448, found 491.0456.

$(4 R, 4 \mathrm{a} S, 12 \mathrm{a} S)-4-A m i n o-3,10,11,12 \mathrm{a}-$ tetrahydroxy-6,9-dimethyl-7-nitro-1,12-dioxo-1,4,4a,5,12,12a-

hexahydrotetracene-2-carboxamide [16] Fuming nitric acid $(10.5 \mu \mathrm{L})$ was added to a solution of CDCHD (20 $\mathrm{mg})$ in sulfolane $(0.5 \mathrm{~mL})$ at $0{ }^{\circ} \mathrm{C}$. The reaction mixture was stirred at $0{ }^{\circ} \mathrm{C}$ for $15 \mathrm{~min}$, quenched with cold water $(100 \mu \mathrm{L})$ and purified by preparative HPLC using acetonitrile / water $(0.1 \%$ formic acid $)$ with a gradient from 20 to $90 \%$ of acetonitrile to afford the pure product as an orange solid $(0.8 \mathrm{mg}, 4 \%)$. ${ }^{1} \mathbf{H}$ NMR (700 $\mathbf{~ M H z}$, Methanol-d $\left.{ }_{4}\right) \delta 8.00(\mathrm{~s}, 1 \mathrm{H}), 4.92(\mathrm{~d}, J=4.4 \mathrm{~Hz}, 1 \mathrm{H}), 3.39(\mathrm{dd}, J=17.3,5.3 \mathrm{~Hz}, 1 \mathrm{H}), 3.28-3.19(\mathrm{~m}, 1 \mathrm{H}), 2.87$ (dd, $J=17.1,12.8 \mathrm{~Hz}, 1 \mathrm{H}), 2.38$ (s, 3H), 2.15 (s, 3H). ${ }^{13} \mathbf{C}$ NMR (176 MHz, Methanol-d $\left.\mathbf{d}_{4}\right) \delta 174.9,163.1,162.9$, 141.3, 136.1, 134.0, 131.6, 120.7, 119.1, 117.5, 111.1, 97.8, 78.7, 54.2, 41.6, 26.6, 17.2, 15.4. HRMS (ESI) calculated for $\mathrm{C}_{21} \mathrm{H}_{20} \mathrm{~N}_{3} \mathrm{O}_{9}(\mathrm{M}+\mathrm{H}) 458.1194$, found 458.1198 .

(4R,4aS,12aS)-4-Amino-3,11,12a-trihydroxy-6,9-dimethyl-1,7,10,12-tetraoxo-1,4,4a,5,7,10,12,12aoctahydrotetracene-2-carboxamide [17] $\mathrm{N}$-iodosuccinimide (45 mg, 5 equiv) was added to a solution of CDCHD (15 mg, 1 equiv) in a mixture AcOH/TFA 1:1 (3 mL) and the reaction mixture was stirred at room temperature for $30 \mathrm{~min}$. After evaporation of volatiles, the obtained crude compound was purified by preparative HPLC using acetonitrile / water ( $0.1 \%$ TFA) with a gradient from 10 to $90 \%$ of acetonitrile to afford the pure quinone compound as a yellow solid (3.5 mg, 17\%). ${ }^{1} \mathbf{H}$ NMR (700 MHz, Methanol-d $\left.{ }_{4}\right) \delta 6.82(\mathrm{~d}, J=1.4 \mathrm{~Hz}$, 1H), 3.42 (dd, $J=18.7,6.6 \mathrm{~Hz}, 1 \mathrm{H}), 3.14$ (ddd, $J=10.9,6.6,4.3 \mathrm{~Hz}, 1 \mathrm{H}), 2.84(\mathrm{dd}, J=18.6,11.0 \mathrm{~Hz}, 1 \mathrm{H}), 2.52$ (s, 3H), 2.15 (d, $J=1.4 \mathrm{~Hz}, 3 \mathrm{H}) .{ }^{13} \mathbf{C}$ NMR (176 MHz, Methanol-d 4 ) $\delta 194.3,191.9,187.8,174.8,162.0,151.2$, 148.3, 139.1, 134.8, 132.5, 124.9, 116.7, 97.9, 78.7, 54.6, 41.1, 28.6, 16.2, 15.5. HRMS (ESI) calculated for $\mathrm{C}_{21} \mathrm{H}_{19} \mathrm{~N}_{2} \mathrm{O}_{8}(\mathrm{M}+\mathrm{H})$ 427.1136, found 427.1136. 


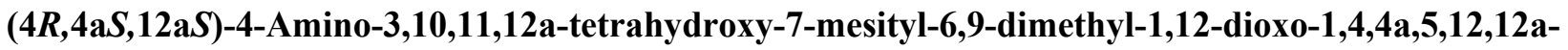

hexahydrotetracene-2-carboxamide [18] To a stirred solution of TFA salt of CDCHD (20 mg, $0.038 \mathrm{mmol}, 1$ equiv) and mesitylene (11 $\mu \mathrm{L}, 0.076 \mathrm{mmol}, 2$ equiv) in HFIP (400 $\mu \mathrm{L})$, acetic acid (4.4 $\mu \mathrm{L}, 0.076 \mathrm{mmol}, 2$ equiv) was added at room temperature. To the mixture, phenyliodine(III) diacetate (PIDA) (12.2 mg, $0.038 \mathrm{mmol}, 1$ equiv) was sequentially added, and the reaction mixture was stirred for an additional $3 \mathrm{~h}$. The reaction mixture was then evaporated under vacuum and purified by preparative HPLC acetonitrile / water $(0.1 \%$ formic acid $)$ with a gradient from 10 to $90 \%$ of acetonitrile to afford the pure product as a red solid ( $3 \mathrm{mg}, 15 \%$ ). ${ }^{1} \mathbf{H}$ NMR (700 MHz, Methanol-d $\left.{ }_{4}\right) \delta 7.05(\mathrm{~s}, 1 \mathrm{H}), 6.89(\mathrm{~s}, 1 \mathrm{H}), 6.86(\mathrm{~s}, 1 \mathrm{H}), 3.17(\mathrm{dd}, J=17.1,5.1 \mathrm{~Hz}, 1 \mathrm{H}), 3.02-2.89$ (m, 1H), $2.72(\mathrm{dd}, J=16.3,13.1 \mathrm{~Hz}, 1 \mathrm{H}), 2.30$ (s, 3H), 2.29 (s, 3H), 1.87 (s, 3H), $1.76(\mathrm{~s}, 3 \mathrm{H}), 1.67$ (s, 3H). ${ }^{13} \mathbf{C}$ NMR (176 MHz, Methanol-d 4 ) $\delta$ 173.7, 157.0, 143.1, 140.2, 137.8, 137.7, 137.3, 137.1, 131.9, 129.6, 129.3, 129.1, 124.7, 121.3, 114.6, 109.9, 79.4, 54.9, 42.1, 27.0, 21.4, 21.3, 21.0, 17.1, 15.7. HRMS (ESI) calculated for $\mathrm{C}_{30} \mathrm{H}_{31} \mathrm{~N}_{2} \mathrm{O}_{7}(\mathrm{M}+\mathrm{H})$ 531.2126, found 531.2121

\section{(4R,4aS,12aS)-4-Amino-3,10,11,12a-tetrahydroxy-7-(4-methoxyphenyl)-6,9-dimethyl-1,12-dioxo-}

1,4,4a,5,12,12a-hexahydrotetracene-2-carboxamide [19] To a stirred solution of TFA salt of CDCHD (20 mg, $0.038 \mathrm{mmol}, 1$ equiv) and anisole $(8.25 \mu \mathrm{L}, 0.076 \mathrm{mmol}, 2$ equiv) in HFIP $(400 \mu \mathrm{L})$, acetic acid $(4.4 \mu \mathrm{L}, 0.076$ mmol, 2 equiv) was added at room temperature. To the mixture, PIDA (18 mg, $0.038 \mathrm{mmol}, 1.5$ equiv) was sequentially added, and the reaxtion mixture was stirred for an additional $3 \mathrm{~h}$. The reaction mixture was then evaporated and purified by preparative HPLC acetonitrile / water $(0.1 \%$ formic acid $)$ with a gradient from 10 to $90 \%$ of acetonitrile to afford the pure product as an orange solid $(2.6 \mathrm{mg}, 13 \%){ }^{1} \mathbf{H}$ NMR (700 $\mathbf{~ M H z}$, Methanold $\mathbf{d}_{4} \delta 7.35(\mathrm{~s}, 1 \mathrm{H}), 7.17(\mathrm{dd}, J=8.3,2.0 \mathrm{~Hz}, 1 \mathrm{H}), 7.05(\mathrm{dd}, J=8.3,1.9 \mathrm{~Hz}, 1 \mathrm{H}), 6.95(\mathrm{dd}, J=8.4,2.5 \mathrm{~Hz}, 1 \mathrm{H})$, $6.91(\mathrm{dd}, J=8.4,2.6 \mathrm{~Hz}, 1 \mathrm{H}), 3.83$ (s, 3H), $3.22(\mathrm{dd}, J=17.0,5.1 \mathrm{~Hz}, 1 \mathrm{H}), 3.14$ (dt, $J=12.6,4.9 \mathrm{~Hz}, 1 \mathrm{H}), 2.68$ (dd, $J=16.8,12.9 \mathrm{~Hz}, 1 \mathrm{H}), 2.32$ (s, 3H), 1.77 (s, 3H). ${ }^{13} \mathbf{C}$ NMR (176 MHz, Methanol-d 4 ) $\delta 200.5,174.9,160.3$, 156.4, 141.3, 138.6, 137.7, 132.4, 131.7, 131.6, 131.3, 125.4, 121.0, 114.9, 114.8, 114.5, 109.7, 97.7, 78.5, 56.0, 55.9, 54.3, 41.9, 26.3, 20.5, 15.6. HRMS (ESI) calculated for $\mathrm{C}_{28} \mathrm{H}_{27} \mathrm{~N}_{2} \mathrm{O}_{8}(\mathrm{M}+\mathrm{H}) 519.1762$, found 519.1767.

(8aS,9R,12aS)-9-Amino-2,2-di-tert-butyl-10,12a-dihydroxy-4,7-dimethyl-12,13-dioxo-8,8a,9,12,12a,13hexahydrotetraceno[1,12-de][1,3,2] dioxasiline-11-carboxamide [20] The Boc-protected CDCHD (20 mg, 0.39 mmol, 1 equiv) was dissolved in DMF ( $2 \mathrm{~mL})$ and then triethylamine ( $30 \mu \mathrm{L}, 0.195 \mathrm{mmol}, 5$ equiv) and the silyl reagent $(25.4 \mu \mathrm{L}, 0.078 \mathrm{mmol}, 2$ equiv) were subsequently added. After $1 \mathrm{~h}$, the reaction mixture was quenched with a saturated aqueous $\mathrm{NH}_{4} \mathrm{Cl}$ solution and then extracted with ethyl acetate. The combined organic layers were dried over sodium sulfate, filtered and evaporated under vacuum. The crude was purified by preparative HPLC using $60 \%$ to $70 \%$ of acetonitrile in water. After lyophilization of the pure fractions, $3 \mathrm{mg}$ of pure Boc-protected silylated compound were obtained (12\%). This compound was dissolved in DCM $200 \mu \mathrm{L}$, and then 2 drops of trifluoroacetic acid were added. The reaction mixture was allowed to stir until completion of the deprotection monitored by LCMS. The reaction mixture was then evaporated and purified by preparative HPLC acetonitrile / water $(0.1 \%$ formic acid) with a gradient from 10 to $90 \%$ of acetonitrile to afford the pure product as a yellow solid (1 mg, 39\%). ${ }^{1} \mathbf{H}$ NMR (500 MHz, Methanol-d 4 ) $\delta 7.54(\mathrm{~d}, J=8.7 \mathrm{~Hz}, 1 \mathrm{H}), 7.48(\mathrm{~d}, J=8.7 \mathrm{~Hz}, 1 \mathrm{H}), 4.81$ 20 
(d, $J=4.3 \mathrm{~Hz}, 1 \mathrm{H}), 3.43$ (dd, $J=17.4,6.9 \mathrm{~Hz}, 1 \mathrm{H}), 3.05$ (ddd, $J=11.3,6.8,4.3 \mathrm{~Hz}, 1 \mathrm{H}), 2.85$ (dd, $J=17.5,11.6$ Hz, 1H), 2.45 (s, 3H), 2.36 (s, 3H), 1.19 (s, 9H), 1.10 (s, 9H). ${ }^{13}$ C NMR (126 MHz, Methanol-d 4 ) $\delta$ 174.9, 153.6, 151.5, 137.5, 134.7, 132.1, 124.9, 122.4, 117.5, 116.4, 115.8, 78.5, 41.6, 27.4, 26.8, 26.7, 22.3, 22.2, 15.6, 14.5. HRMS (ESI) calculated for $\mathrm{C}_{29} \mathrm{H}_{37} \mathrm{~N}_{2} \mathrm{O}_{7}(\mathrm{M}+\mathrm{H}) 553.2365$, found 553.2375.

(6aS,7R,10aS)-7-Amino-9-carbamoyl-8,10a,12-trihydroxy-2,5-dimethyl-10,11-dioxo-6,6a,7,10,10a,11hexahydrotetracen-1-yl acetate [21] TFA-CDCHD (5 mg, $0.0095 \mathrm{mmol}, 1$ equiv) was dissolved in HFIP (300 $\mu \mathrm{L}$ ), and acyl chloride ( $0.095 \mathrm{mmol}, 10$ equiv) was added dropwise. After $2 \mathrm{~h}$ of stirring at room temperature, the reaction mixture was evaporated and subjected to preparative HPLC using water acetonitrile 10 to $90 \%(0.1 \%$ $\mathrm{HCOOH}$ ) as a gradient. After lyophilization of the pure fractions, the desired product was obtained as an orange solid (0.4 mg, 9\%). ${ }^{1} \mathbf{H}$ NMR (700 MHz, Methanol-d 4 ) $\delta 7.88$ (d, $\left.J=8.7 \mathrm{~Hz}, 1 \mathrm{H}\right), 7.64(\mathrm{~d}, J=8.7 \mathrm{~Hz}, 1 \mathrm{H}), 3.43$ (dd, $J=17.1,5.5 \mathrm{~Hz}, 1 \mathrm{H}), 3.15-3.09(\mathrm{~m}, 1 \mathrm{H}), 2.87$ (dd, $J=16.6,13.2 \mathrm{~Hz}, 1 \mathrm{H}), 2.47$ (s, 3H), $2.42(\mathrm{~s}, 3 \mathrm{H}), 2.31$ (s, 3H). ${ }^{13} \mathbf{C}$ NMR (176 MHz, Methanol-d 4$) \delta 171.9,163.1,148.3,139.5,135.2,131.2,129.5,123.6,123.7$, 118.6, 111.5, 78.8, 68.3, 54.4, 41.6, 26.4, 21.2, 16.1, 14.5. HRMS (ESI) calculated for $\mathrm{C}_{23} \mathrm{H}_{23} \mathrm{~N}_{2} \mathrm{O}_{8}(\mathrm{M}+\mathrm{H})$ 455.1449 , found 455.1452 .

\section{(6aS,7R,10aS)-7-Amino-9-carbamoyl-8,10a,12-trihydroxy-2,5-dimethyl-10,11-dioxo-6,6a,7,10,10a,11-} hexahydrotetracen-1-yl 4-bromobenzoate [22] TFA-CDCHD (5 mg, $0.0095 \mathrm{mmol}, 1$ equiv) was dissolved in HFIP $(300 \mu \mathrm{L})$ and 4-bromobenzoyl chloride $(25 \mathrm{mg}, 0.114 \mathrm{mmol}, 12$ equiv) was added dropwise. After $2 \mathrm{~h}$ of stirring at room temperature, the reaction mixture was evaporated and subjected to preparative HPLC using water/acetonitrile 10 to $90 \%(0.1 \% \mathrm{HCOOH})$ as a gradient. After lyophilization of the pure fractions, the desired product was obtained as an orange solid (0.6 mg, 11\%). ${ }^{1} \mathbf{H}$ NMR (700 MHz, Methanol-d $\left.{ }_{4}\right) \delta 8.17(\mathrm{dd}, J=8.5$, $1.9 \mathrm{~Hz}, 2 \mathrm{H}), 7.94(\mathrm{dd}, J=8.7,2.4 \mathrm{~Hz}, 1 \mathrm{H}), 7.81(\mathrm{~d}, J=8.4 \mathrm{~Hz}, 2 \mathrm{H}), 7.69(\mathrm{~d}, J=8.7 \mathrm{~Hz}, 1 \mathrm{H}), 4.81(\mathrm{~d}, J=3.9 \mathrm{~Hz}$, 1H), 3.44 (dd, $J=17.1,5.4 \mathrm{~Hz}, 1 \mathrm{H}), 3.14-3.08$ (m, 1H), $2.91-2.84(\mathrm{~m}, 1 \mathrm{H}), 2.50(\mathrm{~s}, 3 \mathrm{H}), 2.34(\mathrm{~s}, 3 \mathrm{H}) .{ }^{13} \mathrm{C}$ NMR (176 MHz, Methanol-d 4 ) $\delta$ 166.3, 163.0, 148.2, 139.5, 135.2, 133.4, 133.2, 131.4, 130.5, 129.9, 129.7, 123.5, 118.7, 111.5, 78.8, 50.0, 49.7, 41.6, 26.4, 16.1, 14.5. HRMS (ESI) calculated for $\mathrm{C}_{28} \mathrm{H}_{24} \mathrm{BrN}_{2} \mathrm{O}_{8}(\mathrm{M}+\mathrm{H})$ 595.0711 found 595.0717 . 


\section{References}

[1] H.W. Boucher, G.H. Talbot, J.S. Bradley, J. Edwards, John E., D. Gilbert, L.B. Rice, M. Scheld, B. Spellberg, J. Bartlett, Bad Bugs, No Drugs: No ESKAPE! An Update from the Infectious Diseases Society of America, Clin. Infect. Dis., 48 (2009) 1-12.

[2] A. Cassini, L.D. Högberg, D. Plachouras, A. Quattrocchi, A. Hoxha, G.S. Simonsen, M. Colomb-Cotinat, M.E. Kretzschmar, B. Devleesschauwer, M. Cecchini, D.A. Ouakrim, T.C. Oliveira, M.J. Struelens, C. Suetens, D.L. Monnet, B.o.A.C. Group, Attributable deaths and disability-adjusted life-years caused by infections with antibiotic-resistant bacteria in the EU and the European Economic Area in 2015: a population-level modelling analysis, Lancet Infect. Dis., 19 (2019) 56-66.

[3] E. Tacconelli, E. Carrara, A. Savoldi, S. Harbarth, M. Mendelson, D.L. Monnet, C. Pulcini, G. Kahlmeter, J. Kluytmans, Y. Carmeli, M. Ouellette, K. Outterson, J. Patel, M. Cavaleri, E.M. Cox, C.R. Houchens, M.L. Grayson, P. Hansen, N. Singh, U. Theuretzbacher, N. Magrini, Discovery, research, and development of new antibiotics: the WHO priority list of antibiotic-resistant bacteria and tuberculosis, Lancet Infect. Dis., 18 (2018) 318-327.

[4] M. Lakemeyer, W. Zhao, F.A. Mandl, P. Hammann, S.A. Sieber, Thinking Outside the Box-Novel Antibacterials To Tackle the Resistance Crisis, Angew. Chem. Int. Ed. , 57 (2018) 14440-14475.

[5] M. G.Moloney, Natural Products as a Source for Novel Antibiotics, Trends Pharmacol. Sci., 37 (2016) 689-701.

[6] I. Chopra, Tetracycline analogs whose primary target is not the bacterial ribosome, Antimicrob. Agents Chemother., 38 (1994) 637-640.

[7] G.G. B. Oliva, P. McNicholas, G. Ellestad, I. Chopra, Evidence that tetracycline analogs whose primary target is not the bacterial ribosome cause lysis of Escherichia coli, Antimicrob. Agents Chemother., 36 (1992) 913-919.

[8] H.F.N. B. Rasmussen, G. Daubresse, B. Oliva, Z. Misulovin, D.M. Rothstein, G.A. Ellestad, Y. Gluzman, F.P. Tally, I. Chopra, Molecular basis of tetracycline action: identification of analogs whose primary target is not the bacterial ribosome, Antimicrob. Agents Chemother., 35 (1991) 2306-2311.

[9] J.J. Stepanek, T. Lukežič, I. Teichert, H. Petković, J.E. Bandow, Dual mechanism of action of the atypical tetracycline chelocardin, Biochim. Biophys. Acta, 1864 (2016) 645-654.

[10] V. Molnar, Z. Matkovic', T. Tambic', C. Kozma, Lij. Vjes, 99 (1977) 560-562.

[11] M.L. Nelson, M.Y. Ismail , L. Mclntyre, B. Bhatia, P. Viski, P. Hawkins, G. Rennie, D. Andorsky, D. Messersmith, K. Stapleton, J. Dumornay, P. Sheahan, A.K. Verma, T. Warchol, S.B. Levy, Versatile and Facile Synthesis of Diverse Semisynthetic Tetracycline Derivatives via Pd-Catalyzed Reactions, J. Org. Chem., 68 (2003) 5838-5851.

[12] U. Lesnik, T. Lukezic, P. Ajda, J. Horvat, T. Polak, M. Sala, B. Jenko, K. Harmrolfs, A. Ocampo-Sosa, L. Martínez-Martínez, P.R. Herron, S. Fujs, G. Kosec, I.S. Hunter, R. Müller, H. Petkovic, Construction of a New Class of Tetracycline Lead Structures with Potent Antibacterial Activity through Biosynthetic Engineering, Angew. Chem. Int. Ed., 54 (2015) 3934-3940.

[13] T. Lukežič, A. Abou Fayad, C. Bader, K. Harmrolfs, J. Bartuli, S. Groß, U.k. Lešnik, F. Hennessen, J. Herrmann, S.p. Pikl, H. Petković, R. Müller, Engineering Atypical Tetracycline Formation in Amycolatopsis sulphurea for the Production of Modified Chelocardin Antibiotics, ACS Chem. Biol., 14 (2019) 468-477. [14] P.M. Wright, I.B. Seiple, A.G. Myers, The Evolving Role of Chemical Synthesis in Antibacterial Drug Discovery, Angew. Chem. Int. Ed., 53 (2014) 8840-8869.

[15] L.H. Conover, W.T. Moreland, A.R. English, C.R. Stephens, F.J. Pilgrim, Terramycin. XI. Tetracycline, J. Am. Chem. Soc., 75 (1953) 4622-4623.

[16] G. Zhanel, I. Critchley, L.-Y. Lin, N. Alvandib, Microbiological Profile of Sarecycline, a Novel Targeted Spectrum Tetracycline for the Treatment of Acne Vulgaris, Antimicrob. Agents Chemother., 63 (2019) 115. 
[17] A. Markham, S.J. Keam, Omadacycline: First Global Approval, Drugs, 78 (2018) 1931-1937.

[18] J. Berniac, B. Bhatia, M. Grier, M.L. Nelson, J. Pan, 4-aminotetracyclines and methods of use thereof, 2006, WO 2006/047671 A3

[19] D.T.W. Chu, S.N. Huckin, E. Bernstein, Chemistry of chelocardin 11': chemical modifications at C2 and C12a, Can. J. Chem., 55 (1977) 3341-3346.

[20] M.A. Tius, Xenon Difluoride in Synthesis, Tetrahedron, 51 (1995) 6605-6634.

[21] R. Filler, Reactions of Organic Compounds with Xenon Fluorides, Isr. J. Chem., 17 (1978) 71-79.

[22] S. Levy, B., M. Draper, M. Nelson, L., G. Jones, Tetracyclines Compounds Having Target Therapeutic Activities, 2004, WO 2003/005971

[23] S. Rakshit, T. Lakshminarasimhan, S. Guturi, K. Kanagavel, U.R. Kanusu, A.G. Niyogi, S. Sidar, M.R. Luzung, M.A. Schmidt, B. Zheng, M.D. Eastgate, R. Vaidyanathan, Nitration Using Fuming HNO3 in Sulfolane: Synthesis of 6-Nitrovanillin in Flow Mode, Org. Process Res. Dev., 22 (2018) 391-398.

[24] N.C. Bruno, M.T. Tudge, S.L. Buchwald, Design and preparation of new palladium precatalysts for C-C and C-N cross-coupling reactions Chem. Sci., 4 (2013) 916-920.

[25] F.-S. Han, Transition-metal-catalyzed Suzuki-Miyaura cross-coupling reactions: a remarkable advance from palladium to nickel catalysts, Chem. Soc. Rev., 42 (2013) 5270-5298.

[26] Y.-L. Zhao, Y. Li, S.-M. Li, Y.-G. Zhou, F.-Y. Sun, L.-X. Gao, F.-S. Han, A Highly Practical and Reliable Nickel Catalyst for Suzuki- Miyaura Coupling of Aryl Halides, Adv. Synth. Catal., 353 (2011) 1543-1550. [27] D. Maiti, B.P. Fors, J.L. Henderson, Y. Nakamura, S.L. Buchwald, Palladium-catalyzed coupling of functionalized primary and secondary amines with aryl and heteroaryl halides: two ligands suffice in most cases, Chem. Sci., 2 (2011) 57-68.

[28] A. Bruneau, M. Roche, A. Hamze, J.-D. Brion, M. Alami, S. Messaoudi, Stereoretentive PalladiumCatalyzed Arylation, Alkenylation, and Alkynylation of 1-Thiosugars and Thiols Using Aminobiphenyl Palladacycle Precatalyst at Room Temperature, Chem. Eur. J., 21 (2015) 8375-8379.

[29] T.D. Senecal, W. Shu, S.L. Buchwald, A general, practical palladium-catalyzed cyanation of (hetero)aryl chlorides and bromides, Angew. Chem. Int. Ed., 52 (2013) 10035-10039.

[30] A.F. Littke, L. Schwarz, G.C. Fu, Pd/P(t-Bu)3: A Mild and General Catalyst for Stille Reactions of Aryl Chlorides and Aryl Bromides, J. Am. Chem. Soc., 124 (2002) 6343-6348.

[31] S.P.H. Mee, V. Lee, J.E. Baldwin, Significant Enhancement of the Stille Reaction with a New Combination of Reagents-Copper(i) lodide with Cesium Fluoride, Chem. Eur. J., 11 (2005) 3294-3308.

[32] W. Zhu, D. Ma, Synthesis of aryl azides and vinyl azides via proline-promoted Cul-catalyzed coupling reactions, Chem. Commun., (2004) 888-889.

[33] J. Yamaguchi, A.D. Yamaguchi, K. Itami, C-H bond functionalization: emerging synthetic tools for natural products and pharmaceuticals, Angew. Chem. Int. Ed., 51 (2012) 8960-9009.

[34] K. Morimoto, K. Sakamoto, T. Ohshika, T. Dohi, Y. Kita, Organo-lodine(III)-Catalyzed Oxidative Phenol-Arene and Phenol-Phenol Cross-Coupling Reaction, Angew. Chem. Int. Ed., 55 (2016) 3652-3656.

[35] K. Morimoto, Y. Ohnishi, T. Miyamoto, M. Ito, T. Dohi, and Y. Kita, Metal-Free Oxidative para CrossCoupling of Phenols, Chem. Eur. J., 19 (2013) 8726-8731.

[36] B.M. Trost, C.G. Caldwell, E. Murayama, D. Heissler, Sulfur-Substituted Dienes and the Silylene Protecting Group in Synthesis. Deoxypillaromycinone, J. Org. Chem., 48 (1983) 3252-3265.

[37] R.H. Vekariya, J. Aubé, Hexafluoro-2-propanol-Promoted Intermolecular Friedel-Crafts Acylation Reaction, Org. Lett., 18 (2016) 3534-3537.

[38] D.G. Thanassi, G.S.B. Suh, H. Nikaido, Role of Outer Membrane Barrier in Efflux-

Mediated Tetracycline Resistance of Escherichia coli, J. Bacteriol., 177 (1995) 998-1007. 